\title{
Reliability and Validity of the Brief test of Cognitive- Communication Disorders
}

\author{
Mi Sook Lee ${ }^{\mathrm{a}}$, Bo Seon Kim ${ }^{\mathrm{b}}$, Jae Sung Lim ${ }^{\mathrm{c}}$ \\ ${ }^{a}$ Department of Audiology \& Speech-Language Pathology, Hallym University of Graduate Studies HUGS Center for Hearing and Speech Research, \\ Seoul, Korea \\ ${ }^{b}$ Yonsei Speech Language Clinic, Bucheon, Korea \\ 'Department of Neurology, Hallym University Medical Center, Anyang, Korea
}

Correspondence: Bo Seon Kim, PhD Yonsei Speech Language Clinic, 221 Gilju-ro, Wonmi-gu, Bucheon 14547, Korea Tel: +82-32-224-8866

Fax: $+82-2-3453-6618$

E-mail: bskimslp@gmail.com

Received: September 30, 2020

Revised: November 2, 2020

Accepted: November 9, 2020

\begin{abstract}
Objectives: Acquired cognitive-communication disorders (ACCD) will increase rapidly in aged populations. Accordingly, a standardized cognitive-communication test is essential for speech-language pathology. The purpose of this study was to develop the Brief test of Cognitive-Communication Disorders (BCCD) and test its reliability and validity. Methods: A total of 609 normal participants over the age of 55 were divided into groups by age and education. The patients with dementia $(n=116)$, mild cognitive impairment $(n=92)$, traumatic brain injury/right hemisphere damage $(n=51)$, and aphasia $(n=87)$ also performed the BCCD. This measure was completed through several stages that included a pilot study, expert review, and test of face validity, and the final version consisted of 27 items of cognitive-communication domains. Results: There were three main findings. Firstly, the BCCD had high levels of internal consistency, and inter-rater and intra-rater reliabilities. Secondly, verification of the construct validity resulted in a strong correlation between the total mean score of the BCCD and the individual scores of subtests. The concurrent validity also revealed high correspondences. Lastly, the BCCD had an accuracy rate of discriminant function with a high extent of sensitivity and specificity. Conclusion: We showed evidence that the BCCD has diagnostic accuracy as an assessment protocol for a cognitive-communication decline. The findings also have implications for the use of $B C C D$ in planning intervention and improving its effectiveness.
\end{abstract}

Keywords: Acquired-cognitive communication disorders, Cognitive-communication test, Reliability, Validity
치매 인구는 전 세계적으로 약 5,000만 명에 이른다(Christina, 2018). 2050년경에는 1 억 5,200만 명까지 증가할 것이라는 전망도 있다(Wang, Wang, Zhou, Wen, \& Zhen, 2019). 이 같은 추세를 감 안할 때 노화로 인한 신경학적 변화는 반드시 주목해야 할 단계이 며, 치매의 전조 증상인 경도인지장애(mild cognitive impairment, $\mathrm{MCI}$ )는 중요한 임상적 함의를 갖는다(Lee \& Kim, 2019a).

인지-의사소통장애(cognitive-communication disorders, CCD) 는 인지적 결함으로 인해 나타나는 의사소통의 어려움을 의미한다. 즉 주의력, 기억력, 고차원적 인지(higher order cognition, HOC) 등의 결함이 언어 표현 및 이해, 대화, 사회적 의사소통 등에 영향을 미치는 증상이다(ASHA, 2005; Holland, 2010; Lee \& Baik, 2020).
특히 후천적 인지-의사소통장애(acquired cognitive-communication disorders, ACCD)는 언어 특화적인 실어증 등과 구별되는 개 념으로(ASHA, 2005; MacDonald \& Wiseman-Hakes, 2010), 주요 원인 질환은 다음과 같이 분류된다(Cornis-Pop et al., 2012; Lee \& Kim, 2019a). 첫째, 파킨슨병(Parkinson's disease), 헌팅턴병(Huntington's disease), 다발성 경화증(multiple sclerosis) 등의 진행성 신경 질환이다. 둘째, 뇌졸중, 외상성 뇌손상(traumatic brain injury, TBI), 뇌염, 저산소증, 종양 등의 비진행성 신경 질환이다. 셋째, 우울증, 전환장애(conversion disorder) 등의 기타 비진행성 질환이다. $\mathrm{ACCD}$ 를 진단하기 위해서는 다양한 인지 및 의사소통 능력을 평가해야 한다. 인지 영역에는 주의력, 시지각력, 기억력, $\mathrm{HOC}($ 조직 
화 능력, 추론력, 문제해결력, 집행기능 등) 등이 포함된다. 의사소 통 측면에서는 이해 및 표현, 읽기 및 쓰기, 화용언어 등의 영역을 고 려해야한다.

주의력은 다른 인지-의사소통의 기초가 되는 영역이다. 특히 추 론력, 집행기능 등을 포함한 $\mathrm{HOC}$ 및 언어 기능을 발휘하는 데 전 제되어야할 능력으로, 자기 모니터링이나 인지적 자원의 활용과 같 은 상위인지(metacognitive) 능력과도 크게 연관된다(Edwards et al., 2015). 예를 들어, 따라말하기, 읽기 등의 언어 과제를 수행하기 위해서는 주의력, 기억력 등이 뒷받침되어야 한다(Lee \& Kim, 2020a). 주의력의 하위 유형 중 선택주의력(selective attention)과 분리주의 력(divided attention)은 신경학적 변화에 보다 민감하다(Peach \& Shapiro, 2020). 이는 인지적 부담에 따른 처리의 비효율성 측면에 서 설명된다(Vohn, 2008). 즉 처리해야 할 인지적 요구가 분산될수 록 목표물에 주의를 기울이기가 어렵다. 따라서 이중과제(dual-task) 나 다중과제(multitask)와 같이 대립되는 요구 간의 균형이 필요한 경우 주의력의 결함이 더욱 두드러진다. 예컨대, 주의력이 분산되 는 상황에서 언어 과제를 수행하면 인지적 요구에 저항하면서도 동 시에 영향을 크게 받아 단순하고 느린 발화가 산출된다(Kemper, Schmalzried, Hoffman, \& Herman, 2010).

시지각력은 운동 반응, 기억력, 주의력, 시공간적 기술 등의 요소가 결합된 능력으로, 노화나 ACCD의 영향에 취약하다(Lezak, Howieson, \& Loring, 2004). 이는 시공간력이나 시각구성력을 요하는 과 제를 통해 평가된다. 시공간력이 손상되면 공간 내 장소의 국소화, 깊이의 지각, 선의 방향, 도형적 관계, 움직임 등을 처리하기가 어려 우며, 시각구성력은 사물 간의 공간적 관계를 인식하는 데 관여한 다. 예를 들어, 45 세 이상 성인은 기억력에 비해 상대적으로 시공간 력이 저하되고, 50 세 이전의 성인도 복잡한 시각구성 및 시공간 기 능에서 연령 효과가 나타난다(Ferreira et al., 2015; Hoogendam, Hofman, van der Geest, van der Lugt, \& Ikram, 2014). 또 알츠하이 머병(Alzheimer's disease, $\mathrm{AD}$ ), TBI 등에 기인한 $\mathrm{ACCD}$ 는 중증도 가 심화될수록 시지각력의 결함이 두드러진다(Aguerrevere, 2007; Lee \& Kim, 2019a).

기억력은 $\mathrm{ACCD}$ 의 예측 변인으로서 가장 빈번히 논의되는 영역 중 하나이다(Anderson \& Craik, 2017; Lee, 2017). 일화기억(episodic memory)은 병리학적 단계로의 진행을 판별하는 데 유용하며, 이름대기 능력에 관여하는 의미기억(semantic memory)은 $\mathrm{MCI}$ 와 치매 초기부터 뚜렷한 결함을 보인다(Connor, Spiro, Obler, \& Albert, 2004). 작업기억은 다영역 체계로서 기능하므로 주의력의 할 당과 선택, 억제, 업데이트 등 집행기능과 직접적으로 연관된다(Lee \& Kim, 2020b). 신경학적 변화로 인해 작업기억 용량이 축소될 경
우 인지-의사소통 능력이 저하되는 것도 이러한 이유 때문이다. 특 히 읽기 및 듣기 이해, 학습, 계산, 복잡한 구문 구조의 이해 등 언어 이해 측면에 부정적으로 작용한다(Bier et al., 2008; Borella, Carretti, \& De Beni, 2008). 언어 표현에서는 유창성과 문법적 복잡성, 단어 정의 등의 수행을 방해한다(Chow et al., 2006; Peach \& Shapiro, 2020). 언어의 의미, 구문, 화용 능력을 통합적으로 반영하는 담 화도 작업기억에 크게 의존한다(Borella et al., 2008; Kim \& Lee, 2019a).

$\mathrm{HOC}$ 는 추론, 문제해결, 비판적 사고, 학습, 창의성 등을 발휘하 는 데 필요한 과정을 이해하고 적용하는 능력이다(AAAS, 2009). 지각과 실행, 언어 능력 등이 결합해 이러한 고차원적 정신 기능이 발휘되므로(Kumar, Koirala, \& Tiwari, 2015), 개인의 직업 및 일상 생활 뿐 아니라 전반적인 삶의 질에 광범위하게 관여한다. 추론력 은 증거를 기반으로 한 사고, 추론, 결론 유추, 논리적 분석과 관련 된다. 추론의 난이도가 높을수록 인지 처리 속도가 떨어지기 때문 에 노화나 신경학적 질환에 민감하다(Lee \& Kim, 2020a). 조직화 능력은 지각의 단위를 집단으로 묶는 청킹(chunking)이나 집단화 (grouping)에 해당하는데, 작업기억 및 다른 $\mathrm{HOC}$ 기능과의 상관 성 때문에 $\mathrm{ACCD}$ 를 진단할 때 고려해야 할 영역 중 하나이다. 문제 해결력은 과제를 계획하고 사회적 및 감정적 문제를 해결하는 데 요구되며, 일상생활과 직결되어 삶의 질을 좌우하는 기능으로 알려 져 있다(Lee \& Kim, 2020a). 이는 인지 능력 및 기술의 적용, 일상적 경험, 복합적이고 다차원적인 시각 등에 따라 수행이 다를 수 있다. 집행기능은 인지적 통제 기능으로서 $\mathrm{HOC}$ 의 핵심 영역이자 복합 적인 인지 체계를 이룬다. 이 기능 역시 삶의 질 차원에서 매우 결정 적인 역할을 한다(Kumar et al., 2015; Lee \& Kim, 2020a). 즉 신체 적 및 기능적 과제를 수행할 때 인지적 자원의 할당을 조절함으로 써 일상생활을 영위하기 위한 여러 가지 상황에 적용된다. 예를 들 어, 노인은 카드 분류와 같은 과제를 수행할 때 오류의 수가 상대적 으로 많은데, 이는 나이가 들수록 반응 양식을 바꾸기가 어려워 이 전의 기준을 고수하기 때문이다. ACCD 역시 신경학적 기제의 변 화와 이에 따른 복합적 인지 처리의 저하로 $\mathrm{HOC}$ 기능이 떨어진다 (Lee \& Kim, 2020a). 50세 이전부터 저하되기 시작하는 HOC 기능 은 노화나 신경학적 질환으로 인해 보다 악화되며, 궁극적으로 의 사소통의 저하를 초래한다(Singh-Manoux et al., 2012).

$\mathrm{ACCD}$ 의 의사소통 양상은 인지적 수행력과 연계된다. 즉 주의 력, 작업기억, $\mathrm{HOC}$ 등의 저하는 의사소통 기능을 방해한다(Jeong, Sung, \& Sim, 2014; Lee \& Kim, 2018). 의미적 측면의 의사소통 영 역으로서 비유언어, 단어유창성, 단어 정의 등을 꼽을 수 있다.

은유, 모순, 속담, 반어, 역설, 관용구 등의 비유언어를 이해하거 
나 표현할 때 인지적 기제가 크게 관여한다(Uekermann, Thoma, \& Daum, 2008). ACCD 환자는 비유언어를 해석할 때 장황하고 이 야기 중심적이며, 정보를 지나치게 일반화하는 경향이 강하다(Lee, 2017; Treitz, Heyder, \& Daum, 2007).

$\mathrm{ACCD}$ 의 영향에 민감한 또 다른 의사소통 영역으로 단어유창 성(word fluency)이 있다. 이는 신경학적 변화로 인한 언어 지식 자 체의 손실보다는 전반적인 정보 처리 과정의 결함에 기인한다(de Paula \& Malloy-Diniz, 2013; Lee \& Kim, 2019b). 예를 들어, ACCD 로 인해 작업기억이 떨어지면 어휘의 양과 전형성이 감소하며, 연상 전략을 원활히 운용하지 못한다(Choi, 2012; Unsworth, Spillers, \& Brewer, 2012). 실제로 정상 노인이 $\mathrm{AD}$ 로 진전되기 9년 전부터 단어 유창성이 떨어진다는 보고도 있다(Auriacombe et al., 2006; Hodges, Erzinçlioglu, \& Patterson, 2006).

단어 정의는 $\mathrm{HOC}$ 를 포함한 인지-언어적 변화를 잘 반영하는 과 제이다(Kim \& Kim, 2017; Lee \& Kim, 2019b). 문장 수준의 의미론 적인 표현에 그치지 않고 의미적 처리, 의미지식, 상위언어(metalinguistic) 능력, $\mathrm{HOC}$ 등이 복합적으로 작용하기 때문이다. 예를 들 어, 초경도, 경도, 중등도 $\mathrm{AD}$ 로 갈수록 내용의 질적인 차이가 나타 나며, 모든 $\mathrm{AD}$ 환자는 핵심 개념을 간과하거나 부정확한 정보를 산출한다(Kim \& Yoon, 2016; Lee \& Kim, 2019b).

읽기와 쓰기도 교육수준이나 문해 능력, 연령, 신경학적 변화의 영향을 받는다. 특히 $\mathrm{ACCD}$ 로 인해 청각 및 시각 주의력이 저하되 면 읽기 수행력이 제한된다. 연령에 따라서도 차이를 보이는데, 청 년층은 주의를 방해하는 요소가 있을 경우 과제와 연관되더라도 이를 쉽게 무시할 수 있다(Peach \& Shapiro, 2020). 반면 노년층은 방해 요인을 억제하기가 어려워 읽기 속도와 이해력이 떨어지고 내 용을 왜곡하는 경향을 보인다. 지각의 결함도 글자체의 변화를 탐 지하는 데 영향을 미친다(Kemper \& McDowd, 2006). 쓰기 과제는 보다 다양한 변인을 고려해야 한다. 규칙 및 불규칙 단어, 비단어 등 단어 유형, 신경학적 질환 및 과제의 유형 등에 따라 수행력이 다를 수 있다. 예를 들어, 특정 주제에 관해 연상하여 쓰는 과제에는 어 휘-의미 능력이 크게 작용한다. 따라서 대면이름대기 및 단어유창 성 능력과 상관성이 크다(Kim \& Lee, 2019b). ACCD로 인해 쓰기 의 구문적 복잡성이 감소하고 정보 단위가 적은 문장이 산출되기 도 한다(Forbes-McKay, Shanks, \& Venneri, 2014). 글자의 오류나 불분명한 어구도 나타날 수 있다.

화용언어는 정보의 이해 및 처리 속도, 작업기억, 집행기능 등과 고루 연계되므로 $\mathrm{ACCD}$ 의 주요 평가 영역에 해당한다(Lee, 2017; Thompson-Schill, 2002). 특히 담화는 작업기억에 크게 의존하기 때문에 정보의 적절성과 효율성을 통해 의사소통 기능을 파악하
는 데 유용하다(Borella et al., 2008; Lee \& Kim, 2020c). ACCD 환 자는 대화 주제가 일관적으로 유지되지 않고 장황한 발화를 산출 하는 경향이 있다(Ruffman, Murray, Halberstadt, \& Taumoepeau., 2010; Trunk \& Abrams, 2009). 또 사회적 의사결정이나 문제해결 에도 결함이 있어 판단이 변이적이며, 상징언어, 사회적 및 기능적 의사소통이 저하된다(MacPherson, Phillips, \& Della Sala, 2002). 이는 사회적 상호작용을 전반적으로 악화시킬 뿐 아니라(Braver, Satpute, Rush, Racine, \& Barch, 2005), 상징언어, 사회적 및 기능적 의사소통을 발휘하는 데 어려움을 초래한다. 예컨대, 청년층에 비 해 노인은 문맥이 복잡할수록 정보를 효율적으로 운용하지 못하고 목표에 맞게 문맥을 순서화하기가 어렵다(Kim \& Lee, 2019a). 나이 가 들수록 적절한 정보에 대한 민감도가 낮아지기 때문이다. 특히 그림 설명하기, 특정 주제에 대해 말하기 등의 담화 과제에서 발화 의 명제밀도가 연령에 매우 민감하다(Kim \& Lee, 2019a). 이는 신 경학적 변화가 주제 유지의 효율성에 영향을 미치기 때문이다. 문 자 그대로가 아닌 맥락에 따른 화용적 의미를 해석할 경우에도 장 황하고 이야기 중심적인 반응이 많으며 정보를 지나치게 일반화하 는 경향이 있다.

$\mathrm{ACCD}$ 와 관련된 국외 평가도구는 다음의 세 유형으로 분류된 다(Appendix 1). 첫째, 전반적인 ACCD를 대상으로 한 검사에 Arizona Battery for Communication Disorders of Dementia (ABCD; Bayles \& Tomoeda, 1993), Scales of Cognitive Ability of TBI (SCATBI; Adamovich \& Henderson, 1992), Cognitive Linguistic Quick Test (CLQT; Helm-Estabrooks, 2001) 등이 포함된다. 둘째, 실어증 등 $\mathrm{ACCD}$ 로 분류되지 않는 언어장애의 인지-언어적 양상을 평가 하는 도구로 Cognitive Linguistic Quick Test-Plus (CLQT+; HelmEstabrooks, 2017), Temple Assessment of Language and Short-term Memory in Aphasia (TALSA; Martin, Minkina, Kohen, \& Kalinyak-Fliszar, 2018) 등이 활용된다. 셋째, 화용 등 기능적 의사소통 에 중점을 둔 평가도구로서 ASHA Functional Assessment of Communication Skills in Adults (ASHA-FACS; Frattali et al., 2017), Communication Activities of Daily Living-3 (CADL-3; Holland, Fromm, \& Wozniak, 2018) 등이 있다.

$\mathrm{ACCD}$ 의 주요 양상을 고려한 국외 평가도구가 다양화되어 있는 반면, 국내 언어재활 현장에서 활용할 수 있는 표준화 도구는 거의 전무한 실정이다. 실어증 진단도구나 신경심리검사, 기타 언어검사 로 대체할 경우 $\mathrm{ACCD}$ 를 명확히 진단할 수 없으며, 이는 궁극적으 로 중재를 계획하거나 중재 효과를 높이는 데 부정적으로 작용한 다(Lee \& Kim, 2019a). 특히 국내의 고령화 현황을 감안할 때 ACCD 의 효율적인 진단 및 중재의 필요성은 더욱 시급하다(Lee \& Kim, 
2020b). 이에 본 연구는 1) 55 세 이상의 정상군, 2) $\mathrm{ACCD}$ 의 주요 질 환군인 치매, MCI, TBI, 우뇌손상(right hemisphere damage, RHD) 을 대상으로 인지-의사소통의 양상 및 중증도를 진단하는 도구를 제시하고자 하였다. 또 $\mathrm{ACCD}$ 로 분류되지 않는 언어장애인 실어증 군을 추가함으로써 동반된 인지-의사소통 문제를 파악하는 데 활 용하고자 하였다. 이를 위해 인지-의사소통장애 간편검사(Brief test of Cognitive-Communication Disorders, BCCD)의 문항을 개 발한 후 신뢰도와 타당도를 검증하였다. 구체적인 연구 문제는 다 음과같다.

첫째, 정상군 및 환자군을 대상으로 $\mathrm{BCCD}$ 를 적용한 결과를 제 시한다.

둘째, $\mathrm{BCCD}$ 의 신뢰도 및 타당도를 검증한다.

셋째, $\mathrm{BCCD}$ 의 주요 대상군인 치매, $\mathrm{MCI}, \mathrm{TBI} / \mathrm{RHD}$ 집단의 변 별적 기능을 검증한다.

\section{연구방법}

\section{연구대상}

본 연구를 위해 총 609 명의 정상군을 표집하였다. 이들은 수도권 을 포함한 전국 5개 지역에 거주하는 정상인으로, 연령에 따라 55-64

Table 1. Characteristics of normal group

\begin{tabular}{lcccc}
\hline Group & $\begin{array}{c}55-64 \mathrm{yr} \\
(\mathrm{N}=197)\end{array}$ & $\begin{array}{c}65-74 \mathrm{yr} \\
(\mathrm{N}=194)\end{array}$ & $\begin{array}{c}75 \mathrm{yr} \geq \\
(\mathrm{N}=218)\end{array}$ & $\begin{array}{c}\text { Total } \\
(\mathrm{N}=609)\end{array}$ \\
\hline Age (yr) & $59.30(2.60)$ & $70.39(2.93)$ & $77.93(1.97)$ & $69.50(8.11)$ \\
Gender (M:F) & $101: 96$ & 108.86 & $114: 104$ & $323: 286$ \\
Education (yr) & $9.93(4.71)$ & $9.10(4.39)$ & $8.39(4.26)$ & $9.12(4.49)$ \\
K-MMSE & $27.48(2.00)$ & $26.37(2.09)$ & $25.67(2.35)$ & $26.45(2.27)$ \\
\hline
\end{tabular}

Values are presented as mean (SD).

K-MMSE = Korean version of Mini-Mental State Examination (Kang, 2006).
세, 65-74세, 75 세 이상의 세 집단으로 분류되었다. 선정 기준에는 1) 만 55세 이상인 자, 2) 한국형 간이정신상태검사(Korean MiniMental State Examination, K-MMSE)의 정상군 규준(Kang, 2006) 에 의거해 정상 범주에 속하는 자, 3) 신경학적 질환 및 청력 문제가 없는 자가 포함되었다. 정상군은 교육연수에 따라 비문해 및 0년, 1-6년, 7-12년, 13 년 이상의 4 개 집단으로 세분화되었다. 지역 분포 (\%)는 수도권 49.6 , 경상권 25.8 , 전라권 10.8 , 충청권 10.8 , 강원권 3.0 이었고, 집단 간의 성별 분포에는 유의미한 차이가 없었다 $\left(\chi^{2}=\right.$ $.836, p=.658)$. 정상군의 인구통계학적 특성은 Table 1 에 제시하였다.

본 연구에 참여한 환자군은 치매 116명, MCI 92명, TBI 및 RHD 51 명, 실어증 87 명으로 구성되었다. 수도권, 충청권, 강원권 소재의 대학병원 신경과 및 재활의학과, 데이케어센터, 대학 부설 언어재활 센터, 요양병원, 재활병원 등에 내원 또는 입원 중인 자들이 참여하 였고, 전문의에 의해 치매, MCI, TBI 및 RHD, 그리고 언어재활사 에 의해 실어증으로 진단되었다. 치매군은 경도-심도의 알츠하이머 형 치매(Alzheimer's dementia)와 혈관성 치매(vascular dementia) 로 구성되었다. MCI군의 하위 유형은 기억상실형(amnestic) 및 비 기억상실형(nonamnestic), 단일영역형(single-domain) 및 다영역 형(multiple-domain) $\mathrm{MCI}$ 였다. TBI 및 RHD, 실어증 집단의 중증 도는 경도-중등도였으며, 실어증의 유형에는 전반실어증, 브로카실 어증, 연결피질운동실어증, 베르니케실어증, 연결피질감각실어증, 이름실어증 등 6 개 유형이 포함되었다. 실어증 환자군 중 전반실어 증 유형은 총 1 명으로, 실어증지수(AQ)는 35.2/100였다. 환자군의 인구통계학적 특성, 유형 및 중증도 등은 Table 2에 제시하였다.

\section{연구도구}

$\mathrm{BCCD}$ 는 인지 15 개, 의사소통 12 개 등 총 27 개 문항으로 구성되 었다. 인지의 4 개 하위 검사에는 1) 주의력(선택주의력, 분리주의

Table 2. Characteristics of patient group

\begin{tabular}{lcccc}
\hline Group & Dementia (N=116) & MCl (N=92) & TBI/RHD (N=51) & Aphasia (N=87) \\
\hline Age (yr) & $76.83(6.54)$ & $73.92(6.34)$ & $73.63(6.39)$ & $77.52(5.31)$ \\
Gender (M:F) & $46: 70$ & 36.56 & $20: 31$ & $40: 47$ \\
Education (yr) & $8.28(3.87)$ & $8.79(3.57)$ & $9.00(3.56)$ & $7.53(2.16)$ \\
K-MMSE & $18.74(4.63)$ & $21.83(4.55)$ & $21.25(4.76)$ & $19.78(6.83)$ \\
Subtype & Alzheimer's/Nascular & Amnestic/ Nonamnestic/single- & $\cdot$ & Gobal/Broca's/TM/Wernicke's/ \\
& & domain/multiple-domain & TS/Naming \\
Severity & Mild-Severe & $\cdot$ & Mild-Moderate & Mild-Moderate \\
Diagnostic index & CDR/GDS & CDR & K-WAB/PK-WAB-R \\
\hline
\end{tabular}

Values are presented as mean (SD).

$\mathrm{MCl}=$ mild cognitive impairment; $\mathrm{TBI}=$ traumatic brain injury; RHD= right hemisphere damage; K-MMSE=Korean version of mini-mental state examination (Kang, 2006); $\mathrm{TM}=$ transcortical motor; $\mathrm{TS}=$ transcortical sensory; $\mathrm{CDR}=$ clinical dementia rating; $\mathrm{GDS}=$ global deterioration scale; $\mathrm{K}-\mathrm{WAB}=$ Paradise Korean version-Western aphasia battery (Kim \& Na, 2001); PK-WAB-R=Paradise Korea-Western aphasia battery-revised (Kim \& Na, 2012). 
력), 2) 시지각력(시공간구성), 3) 기억력(작업기억, 회상 및 재인), 4) $\mathrm{HOC}$ (조직화능력, 추론력, 문제해결력, 집행기능)가 포함되었다. 의사소통의 하위 검사는 1) 이해(비유언어, 상징 및 기호), 2) 표현 (단어유창성, 단어 정의, 비유언어), 3) 읽기 및 쓰기(읽기이해, 받아 쓰기), 4) 화용언어(담화/화용표현) 4 개 영역으로 구성되었다. 화용 언어의 담화를 제외한 나머지 문항은 모두 각각 0-2점이 부여되며, 담화 문항은 명시된 기준에 따라 최대 8 점까지 산정된다. $\mathrm{BCCD}$ 의 세부 구성은 Table 3 과 같다.

하위 영역별로 적용된 과제를 살펴보면 다음과 같다. 선택주의력 은 청각 자극, 분리주의력은 청각 및 시각 자극에 각각 반응하도록 하였다. 시지각력은 그리기 과제를 통해 시공간구성력을 평가하였 고, 구어 작업기억은 청각적으로 제시되는 단어(예: 양말-개)의 순 서 기억하기, 비구어 작업기억은 도형의 모양 기억하기로 구성하였 다. 기억력 중 ‘회상 및 재인’은 담화 과제에서 제시된 지문의 내용을 기억하는 과제로 평가하였다. $\mathrm{HOC}$ 는 인지 체계의 활성화, 목표의 유지나 과제의 지속, 행동-순서의 조직화, 인식 또는 자기모니터링 과 수정, 억제, 시간 배분, 업데이트, 전환 등을 반영하는 집약적인 과제로 구성되었다(예: 주어진 상황에 대한 해결 방법 말하기). 비유 언어 이해는 인지와 언어, 화용, 세상 지식(world knowledge)이 연 계된 고차원적 사고와 복잡한 언어 처리의 주요 지표를 파악하기

Table 3. Construction of BCCD

\begin{tabular}{|c|c|c|c|}
\hline Domain & $\begin{array}{l}\text { Subdomain } \\
\text { (Total score) }\end{array}$ & Detail & $\begin{array}{l}\text { Number } \\
\text { of items }\end{array}$ \\
\hline \multirow[t]{10}{*}{ Cognition } & \multirow[t]{2}{*}{ Attention (4) } & Selective attention & 1 \\
\hline & & Divided attention & 1 \\
\hline & Visuoperception (2) & Visuospatial construction & 1 \\
\hline & \multirow[t]{2}{*}{ Memory (6) } & Working memory (verbal/nonverbal) & 2 \\
\hline & & Recall \& recognition & 1 \\
\hline & \multirow{4}{*}{$\begin{array}{l}\text { Higher order cogni- } \\
\text { tion (18) }\end{array}$} & Organization & 2 \\
\hline & & Reasoning & 2 \\
\hline & & Problem solving & 3 \\
\hline & & Executive function & 2 \\
\hline & Subtotal (30) & & 15 \\
\hline \multirow{10}{*}{$\begin{array}{l}\text { Communi- } \\
\text { cation }\end{array}$} & \multirow[t]{2}{*}{ Comprehension (8) } & Figurative language & 3 \\
\hline & & Symbol \& sign & 1 \\
\hline & \multirow[t]{3}{*}{ Expression (8) } & Word fluency & 2 \\
\hline & & Word definition & 1 \\
\hline & & Figurative language & 1 \\
\hline & \multirow{2}{*}{ Reading/Writing (4) } & Reading comprehension & 1 \\
\hline & & Dictation & 1 \\
\hline & \multirow{2}{*}{$\begin{array}{l}\text { Pragmatic language } \\
\text { (10) }\end{array}$} & Discourse & 1 \\
\hline & & Pragmatic expression & 1 \\
\hline & \multicolumn{2}{|l|}{ Subtotal (30) } & 12 \\
\hline \multicolumn{3}{|c|}{ BCCD total (60) } & 27 \\
\hline
\end{tabular}

$\mathrm{BCCD}=$ Brief test of Cognitive-Communication Disorders.
위해 속담, 비유, 관용구에 대한 해석 과제를 활용하였다. 단어유창 성은 범주의 속성, 빈도, 선행 도구와의 중복성 등을 고려한 '생물' 범주의 의미적 단어유창성, 그리고 한국 성인의 구어 및 사전 표제 어상의 음소 빈도(Shin, 2008)를 기초로 노화 및 치매의 영향에 민 감한 음운적 단어유창성으로 이원화하였다. 쓰기 문항의 문장 자 극을 선정하는 데에는 규칙 및 불규칙 단어의 비율을 우선적으로 고려하였다. 즉 자소와 음소 간 대응을 기준으로 글자-소리의 일치 성 여부에 기반한 규칙 및 불규칙 단어를 균일하게 포함하였다. 담 화는 문단자극을 제시한 후 ‘다시 말하기' 과제를 시행하여 응집성 (cohesion), 통일성(coherence), 명제, 쉼을 분석하는 방식으로 구성 되었다.

\section{연구절차}

예비 문항의 개발

$\mathrm{BCCD}$ 의 예비 문항을 개발하기 위해 다양한 문헌을 검토하였다. 또 $\mathrm{ACCD}$ 에 특화된 국내 도구로서 외상성 뇌손상 환자의 인지-화 용언어 능력 평가도구(Cognitive-pragmatic language ability Assessment Protocol for Traumatic Brain Injury, CAPTBI; Lee, 2013) 에 포함된 인지 및 언어 문항을 참고하였다. 국외에서 출판되거나 연구된 도구들은 ACCD 및 실어증의 인지-의사소통, 기능적 인지의사소통의 세 유형으로 분류해 검토하였다(Lee \& Kim, 2019a).

\section{전문가 검토 및 안면타당도 구축}

언어병리학 전공 교수 및 1 급 언어재활사 각 2 인, 신경과 전문의 및 임상심리사 각 1 인 등 총 6 인으로 구성된 전문가 검토를 2 회에 걸쳐 시행하였다. 이를 통해 선정된 문항을 총 32 명의 정상 노인에 게 적용함으로써 안면타당도를 검증하였다. 먼저 지시문을 듣고 이 해하는 데 어려움이 있는 문항을 확인하였다. 이밖에 해당 영역의 평가에서 각 문항의 적절성 여부, 검사 의도를 과도하게 드러내는 지 여부 등을 알아보았다. 전문가 검토 및 안면타당도 구축의 결과 를 토대로 $\mathrm{BCCD}$ 의 예비 문항을 수정한 후 27 개의 최종 문항을 선 정하였다(Lee \& Kim, 2019a).

\section{$\mathrm{BCCD}$ 의 적용}

정상군 및 환자군을 대상으로 $\mathrm{BCCD}$ 의 최종 문항을 적용하였 다. 인구통계학적 및 신경학적 정보, 청력과 시력 등의 기타 정보에 대한 사례면담을 실시하였고, 인지 능력의 선별 및 공인타당도의 검증을 위해 K-MMSE와 실어증-신경언어장애 선별검사(Screening Test for Aphasia and Neurologic-communication Disorders, STAND; Kim, Heo, Kim, \& Kim, 2008)를 추가로 시행하였다. 검 
사는 소음이 최소화된 공간에서 검사자가 직접 대상군을 평가하 였고, 수행력은 문항별 특성에 따라 검사자가 기록지에 기재하거나 피검자가 반응지에 직접 표기하도록 하였다. 평균 검사 시간은 사 례면담 및 추가 검사의 경우 $10-15$ 분, $\mathrm{BCCD}$ 의 경우 정상군 $15-20$ 분, 환자군 20-30분 가량 소요되었다.

$\mathrm{BCCD}$ 의 문항은 담화를 제외하고 모두 3점 척도 $(2,1,0)$ 로 채점 하였고, 세부 채점 기준은 문항의 특성에 따라 다르게 적용하였다. 예를 들어, 주의력은 정반응 수와 반응시간, 기억력은 정반응 수, 시 지각력 및 단어정의 등은 명시된 채점 기준(예: 먹을 때 사용)에 따 라 채점하였다. 화용의 담화 문항은 분석 기준(예: 6 개 명제 이상을 회상하여 말한 경우)에 따라 최대 8점을 부여하였다. 지표별로 분 류하여 응집성과 통일성은 각각 0-3점, 명제와 심은 각각 0-2점으로 평정하였다. $\mathrm{BCCD}$ 의 점수가 높을수록 인지-의사소통 능력이 양 호함을 의미한다.

\section{통계분석}

본 연구에서는 SPSS 25.0 version (Statistical Product and Service Solution 25.0)을 통계분석 프로그램으로 활용하였다. 집단 간 성별 분포의 차이를 확인하기 위해 카이제곱 검정 $\left(\chi^{2}\right.$ test $)$ 을 시행하였고, 정상군 및 환자군의 수행력은 일원배치 분산분석(one-way analysis of variance, one-way ANOVA) 및 Tukey 사후검정, 독립표본 $t$ 검정(independent samples $t$-test)으로 분석하였다. 신뢰도 및 타당 도는 피어슨 상관계수(Pearson correlation coefficient) 분석, 내적 일관성신뢰도 분석을 활용하였고, 판별분석(discriminant analysis), Receiver Operating Characteristic (ROC)을 통해 BCCD의 진 단적 기능을 알아보았다.

\section{연구결과}

\section{$\mathrm{BCCD}$ 의 적용}

정상군의 인지 및 의사소통 총점, $\mathrm{BCCD}$ 총점은 세 연령 집단을 4 개 교육연수별로 세분화한 후 비교하였다. 그 결과 3 개 연령 및 4 개 교육연수 집단 간의 차이가 모두 유의하였다 $(p<.01)$. 사후검정 결과 모든 두 집단 간의 차이도 유의미한 것으로 나타났다 $(p<.01)$

Table 4. Results of BCCD in patient group

\begin{tabular}{lcccc}
\hline Domain (total score) & Dementia & \multicolumn{1}{c}{ MCl } & TBI/RHD & \multicolumn{1}{c}{ Aphasia } \\
\hline Cognition total (30) & $18.92(4.91)$ & $19.39(6.50)$ & $18.75(6.29)$ & $17.91(7.32)$ \\
Communication total (30) & $15.71(4.23)$ & $17.46(5.16)$ & $16.46(6.64)$ & $15.00(6.66)$ \\
BCCD total (60) & $34.55(8.67)$ & $36.85(11.15)$ & $35.20(12.64)$ & $32.91(13.77)$ \\
\hline
\end{tabular}

$\mathrm{BCCD}=$ Brief test of Cognitive-Communication Disorders.
즉 연령 측면에서 55-64세와 65-74세 집단, 55-64세와 75세 이상 집 단, 65-74세와 75세 이상 집단 간, 그리고 교육연수 측면에서 비문 해/0년과 1-6년 집단, 비문해/0년과 7-12년 집단, 비문해/0년과 13년 이상 집단, 1-6년과 7-12년 집단, 1-6년과 13년 이상 집단, 7-12년과 13 년 이상 집단 간에 각각 유의한차이가 있었다. 연령 집단 별 $\mathrm{BCCD}$ 총점(60점)은 55-64세군 49.40 ( \pm 5.86 ), 65-74세군 42.47 ( \pm 8.95 ), 75세 이상군 38.83 ( \pm 7.94 )이었다. 교육연수별로는 비문해/0년군 30.75 ( \pm 5.88), 1-6년군 36.94 ( \pm 6.97 ), 7-12년군 46.05 ( \pm 6.13 ), 13 년 이상군 $51.00( \pm 6.77)$ 으로 분석되었다.

4 개 환자군의 인지 및 의사소통 총점, $\mathrm{BCCD}$ 총점을 비교한 결과, 정상군과 각 환자군 간에 모두 유의미한 차이가 있었다 $(p<.01)$. 즉 정상군과 치매군, 정상군과 $\mathrm{MCI}$ 군, 정상군과 $\mathrm{TBI} / \mathrm{RHD}$ 군, 정상군 과 실어증군 간의 수행력 차이가 유의한 것으로 나타나, 각 환자군 이 정상군에 비해 인지-의사소통 능력이 낮음을 알 수 있었다. 치 매, $\mathrm{MCI}, \mathrm{TBI} / \mathrm{RHD}$, 실어증 집단의 $\mathrm{BCCD}$ 총점은 각각 34.55 ( \pm 8.67), 36.85 ( \pm 11.15$), 35.20$ ( \pm 12.64$), 32.91$ ( \pm 13.77$)$ 로 분석되었 다(Table 4).

\section{신뢰도}

내적 일관성신뢰도

정상군의 수행력에 근거해 내적 일관성신뢰도를 알아본 결과, $\mathrm{BCCD}$ 의 전체 문항에 대한 Cronbach's $\alpha$ 계수는 .837로 높게 나타 났다. 각 하위 검사별 계수는 Table 5 에 제시하였다.

\section{검사자 간 검사자 내 신뢰도}

치매 및 $\mathrm{MCI}$ 환자군의 $10 \%$ 를 대상으로 검사자 간 및 검사자 내 신뢰도를 알아보았다. 검사자는 공통적으로 1) 언어병리학 석사 학 위 이상, 2) 1 급 언어재활사 국가자격증 소지자, 3) 신경언어장애 관 련 임상 경력 7년 이상인 자였고, 검사자 내 신뢰도를 위한 검사-재

Table 5. Internal consistency reliability of BCCD (Cronbach $\alpha=$.837)

\begin{tabular}{llcc}
\hline Domain (total score) & \multicolumn{1}{c}{ Subtest } & CITI & $\begin{array}{c}\text { Cronbach } \alpha \text { if item } \\
\text { deleted }\end{array}$ \\
\hline Cognition & Attention & .513 & .828 \\
& Visuoperception & .321 & .844 \\
& Memory & .654 & .813 \\
& Higher order cognition & .576 & .831 \\
Communication & Comprehension & .658 & .805 \\
& Expression & .786 & .784 \\
& Reading/Writing & .673 & .829 \\
& Pragmatic language & .744 & .791 \\
\hline
\end{tabular}

$\mathrm{CITI}=$ Corrected Item Total Correlation. 
검사간의 시행 간격은 2 주였다.

검증 결과, 검사자 2인에 대한 검사자 간 신뢰도는 $.992(p<.01)$ 이상으로 높게 나타났다. 검사자 내 신뢰도는 $.999(p<.01)$ 이상으 로 시간의 경과에 따른 평가의 신뢰도가 매우 높았다.

\section{타당도}

\section{내적 구성타당도}

치매 및 $\mathrm{MCI}$ 환자군의 수행력에 근거해 $\mathrm{BCCD}$ 의 내적 구성타당 도를 분석하였다(Appendix 2). 각 하위 검사와 총점 간 상관관계를 살펴본 결과 대부분의 영역 간 유의한 상관성이 있었다. 치매군에 서는 대부분의 하위 영역 간 유의한 상관성을 보인 반면 $(p<.05$, $p<.01)$, 주의력과화용언어간의 상관성은 유의하지 않았다 $(p=171)$. $\mathrm{MCI}$ 군의 경우 대부분의 영역 간에 유의한 상관성이 있었다 $(p<.05$, $p<.01)$. 그러나 화용언어와 주의력 $(p=.194)$, 화용언어와 시지각력 ( $p=.187)$, 화용언어와 HOC ( $p=.129)$, 화용언어와 인지 총점 $(p=$ .201) 간의 상관성은 유의미하지 않은 것으로 분석되었다.

\section{공인타당도}

환자군의 하위 검사 별 수행력을 토대로 $\mathrm{BCCD}$ 의 공인타당도를 알아보았다. 이를 위해 치매 및 $\mathrm{MCI}$, 실어증 집단의 주의력, 시지각

Table 6. Concurrent validity of BCCD

\begin{tabular}{|c|c|c|c|c|c|c|}
\hline \multirow[b]{2}{*}{ Subtest } & \multirow[b]{2}{*}{ Group } & \multicolumn{5}{|c|}{ BCCD } \\
\hline & & Attention & $\begin{array}{l}\text { Visuo-per- } \\
\text { ception }\end{array}$ & Memory & $\begin{array}{l}\text { Communi- } \\
\text { cation to- } \\
\text { tal score }\end{array}$ & $\begin{array}{l}\text { BCCD to- } \\
\text { tal score }\end{array}$ \\
\hline \multicolumn{7}{|l|}{ K-MMSE } \\
\hline \multirow[t]{3}{*}{ Attention } & Dementia & $.924^{* *}$ & & & & \\
\hline & $\mathrm{MCl}$ & $.859^{* *}$ & & & & \\
\hline & Aphasia & $.967^{* *}$ & & & & \\
\hline \multirow[t]{3}{*}{ Drawing } & Dementia & & $.502^{* *}$ & & & \\
\hline & $\mathrm{MCl}$ & & $.848^{* *}$ & & & \\
\hline & Aphasia & & $.770^{* *}$ & & & \\
\hline \multirow[t]{3}{*}{ Memory } & Dementia & & & $.989 * *$ & & \\
\hline & $\mathrm{MCl}$ & & & $.990^{* *}$ & & \\
\hline & Aphasia & & & $.992^{* *}$ & & \\
\hline \multirow[t]{3}{*}{ Language } & Dementia & & & & $.872^{* *}$ & \\
\hline & $\mathrm{MCl}$ & & & & $.904^{* *}$ & \\
\hline & Aphasia & & & & $.795^{* *}$ & \\
\hline \multirow[t]{3}{*}{ Total score } & Dementia & & & & & $.880^{* *}$ \\
\hline & $\mathrm{MCl}$ & & & & & $.957^{* *}$ \\
\hline & Aphasia & & & & & $.879^{* *}$ \\
\hline
\end{tabular}

$\mathrm{BCCD}=$ Brief test of Cognitive-Communication Disorders; K-MMSE $=$ Korean version of mini-mental state examination (Kang, 2006); $\mathrm{MCl}=$ mild cognitive impairment. ${ }^{* *} p<.01$.
력, 기억력, 의사소통 총점, $\mathrm{BCCD}$ 총점을 $\mathrm{K}-\mathrm{MMSE}$ 의 해당 영역과 비교하였다. 그 결과 각 영역 간의 상관관계가 모두 유의하게 나타 났다(Table 6).

$\mathrm{BCCD}$ 의 의사소통 영역은 STAND를 통해 검증하였다. 실어증 환자군의 이해, 표현, 읽기/쓰기, 화용언어, 총점은 각각 STAND의 듣고 이해하기, 이름대기, 읽기/쓰기, 그림 설명하기, 총점과 .865.987 ( $p<.01)$ 수준에서 모두 유의미한 상관성이 있었다.

\section{변별적 기능}

\section{진단정확도}

$\mathrm{BCCD}$ 의 진단정확도를 알아보기 위해 정상군과 환자군의 수행 력에 대한 판별분석을 실시하였다(Table 7). 치매군의 경우 정준상 관계수는 .73으로 높았고, Wilks의 람다(Lamda) 값은 .47( $p<.01)$ 로 유의하였다. $\mathrm{MCI}$ 군은 정준상관계수 .62, Wilks의 람다 값 .62 $(p<.01)$ 로 변별력이 유의한 것으로 나타났다. 이에 근거한 $\mathrm{BCCD}$ 의 판별기능 적중률은 각각 $88.50 \%$ 와 $88.20 \%$ 로 인지-의사소통장 애 평가도구로서 높은 예측력이 있음을 알 수 있었다. TBI/RHD군 은 정준상관계수 .69, Wilks의 람다 값 $.57(p<.01)$, 판별기능 적중 률 $88.30 \%$ 로 진단정확도가 유의한 것으로 분석되었다.

\section{민감도 및 특이도}

정상군과 환자군을 변별하는 절단점, 민감도 및 특이도를 산출 하기 위해 Receiver Operating Characteristic (ROC) 분석을 시행 한 결과를 Table 8 에 제시하였다. 정상군과 치매군을 변별하는 지

Table 7. Diagnostic accuracy of BCCD

\begin{tabular}{lccc}
\hline Group & $\begin{array}{c}\text { Standardized canonical dis- } \\
\text { criminant function coefficients }\end{array}$ & $\begin{array}{c}\text { Wilks' } \\
\text { lambda }\end{array}$ & $\begin{array}{c}\text { Accuracy rate of dis- } \\
\text { criminant function (\%) }\end{array}$ \\
\hline Dementia & .73 & $.47^{* *}$ & 88.50 \\
$\mathrm{MCl}$ & .62 & $.62^{* *}$ & 88.20 \\
$\mathrm{TBI} / \mathrm{RHD}$ & .69 & $.57^{* *}$ & 88.30 \\
\hline
\end{tabular}

$\mathrm{BCCD}=$ Brief test of Cognitive-Communication Disorders; $\mathrm{MCl}=$ mild cognitive impairment.

${ }^{* *} p<.01$.

Table 8. Sensitivity and specificity of BCCD

\begin{tabular}{llccc}
\hline Group & AUC & Cut-off score & Sensitivity (\%) & Specificity (\%) \\
\hline Dementia & $.94^{* *}$ & 42.91 & 87.00 & 87.00 \\
MCI & $.95^{* *}$ & 47.55 & 89.60 & 89.10 \\
TBI/RHD & $.94^{* *}$ & 44.84 & 83.50 & 89.10 \\
\hline
\end{tabular}

$\mathrm{BCCD}=$ Brief test of Cognitive-Communication Disorders; $\mathrm{AUC}=$ area under the curve; $\mathrm{MCl}=$ mild cognitive impairment.

${ }^{* *} p<.01$. 
표로서 절단점 42.91 점, 민감도 $87.00 \%$, 특이도 $87.00 \%$ 로 분석되었 다. $\mathrm{MCI}$ 의 경우 절단점 47.55 점, 민감도 $89.60 \%$, 특이도 $89.10 \%$ 로 나타났다. TBI/RHD군은 절단점 44.84점, 민감도 $83.50 \%$, 특이도 $89.10 \%$ 로 나타났다.

\section{논의 및 결론}

본 연구는 1) 55세 이상의 정상 성인, 2) 치매, $\mathrm{MCI}, \mathrm{TBI} / \mathrm{RHD}$ 등 $\mathrm{ACCD}$ 의 주요 질환군, $3 \mathrm{ACCD}$ 로 분류되지 않는 언어장애인 실 어증을 대상으로 인지-의사소통의 양상 및 중증도를 진단하는 도 구로서 $\mathrm{BCCD}$ 를 개발하고 신뢰도 및 타당도, 변별적 기능을 알아 보았다.

\section{$\mathrm{BCCD}$ 의 적용}

$\mathrm{BCCD}$ 를 적용한 결과 정상군의 3 개 연령 및 4 개 교육연수 집단 별로 모두 유의미한 차이를 보였고, 모든 두 집단 간의 차이도 유의 하였다. 인지-의사소통 측면에 나타나는 연령 효과는 ACCD의 주 요 변인 중 하나이다. 이는 노년층 뿐 아니라 청년층과 장년층, 장년 층과 노년층 간에도 해당한다(Hoogendam et al., 2014). 노년층의 경우에도 연소 노인, 중고령 노인, 초고령 노인 등 세분화된 연령별 로 유의미한 차이를 보인다(Kim \& Lee, 2019a; Lee \& Kim, 2018; Lee \& Kim, 2019a).

특히 본 도구는 연령 효과에 민감한 하위 영역들로 구성되어 있 어 이러한 차이가 더욱 두드러지게 나타났다. 예컨대, 주의력 중 선 택주의력과 분리주의력은 대립되는 과제의 요구 간에 균형이 필요 하므로 연령 간의 차이가 뚜렷한 영역이다(Kemper et al., 2010). 또 기억력의 하위 검사로서 구어 및 비구어 작업기억이 포함된 점도 이와 동일한 맥락이다. 작업기억 용량은 뉴런의 수축, 시냅스(synapse) 밀도의 감소 등에 의한 전전두피질의 변화를 반영하는데, 이 는 연령에 매우 민감한 신경학적 기제이다(Goral et al., 2011). BCCD 의 의사소통이 비유언어, 상징/기호, 담화 등 기능적 및 화용적 영 역으로 구성되어 $\mathrm{HOC}$ 와의 상관성을 반영한 점도 연령 효과와 직 결된다(Lee \& Kim, 2020a; Singh-Manoux et al., 2012). 언어의 어 휘-의미 측면, 정보 처리의 효율성, 작업기억의 영향 등에 근거해 단 어유창성, 단어정의와 같은 표현 영역에 주목한 점도 본 결과에 기 여한 것으로 간주된다.

본 연구에서 4 개 교육연수 집단 간의 차이가 유의한 것은, 교육 수준이 정상 노인의 인지-의사소통에 변인으로 작용함을 반영한 다(Ganguli et al., 2010). 이의 근거는 다음과 같다. 첫째, 지적 구조 의 변화 가설로서, 인간의 지적 구조는 전 생애에 걸쳐 변화하므로
지적 구조의 역동성을 강조하는 관점이다. 특히 반성적 사고, 논리 와 감정 사이의 균형 감각, 현실적 및 주관적 요인, 정서 등에 중점 을 두는 '후형식적 사고(postformal thought)'는 교육수준의 영향 력을 뒷받침한다(Labouvie-Vief \& Diehl, 1999). 따라서 교육은 노 화로 인한 인지-언어적 퇴행을 막고, 지적 구조의 역동성에 크게 기 여한다. 둘째, 인지보존 능력(cognitive reserve)의 관점이다. 노화나 신경학적 손상으로 인해 인지적 변화가 발생하더라도 이에 효율적 으로 대처할 수 있는 뇌 기능으로, 교육수준은 이의 가장 강력한 경험적 변인이다(Lee, 2015; Stern, 2009). 실제로 신경학적 질환이 있는 노인의 경우 인지보존 능력으로 인해 임상적 징후나 증상이 드러나지 않기도 한다(Mortimer, Snowdon, \& Markesbery, 2003). 셋째, 결정성 지능(crystallized intelligence)의 관점으로, 교육수준 을 포함해 문화적 경험, 직업, 문화 및 지적 활동의 빈도 등이 인지의사소통의 수행에 영향을 미친다는 개념이다(Anstey \& Low, 2004). 이는 치매의 초기 단계나 뇌손상 이후에도 보존되며, 20 대 중반부 터 70대에 이르기까지 유사한 수준으로 유지된다. 요컨대, 교육수 준이 인지-의사소통에 미치는 영향을 뒷받침하는 근거는 다양하 나 교육연수가 많을수록 이러한 기제들이 보다 활성화됨을 의미한 다(Lee, Kawachi, Berkman, \& Grodstein, 2003).

$\mathrm{BCCD}$ 의 $\mathrm{HOC}$ 영역은 교육수준과 인지-의사소통 간의 이 같은 상관성을 크게 반영하였다. 즉 지각과 실행, 언어 등을 결합한 $\mathrm{HOC}$ 문항을 통해 교육수준에 따른 차이가 두드러지도록 구조화되었다. 따라서 학습과 인지 자극에 노출된 경험이 많을수록 지적 구조의 역동성과 인지보존 능력 등이 강화됨으로써 높은 수준의 인지-의 사소통 수행력으로 연계된다. 특히 $\mathrm{BCCD}$ 의 의사소통 영역에서 비 유언어의 이해 및 표현 문항은 작업기억, 화용적 추론, 집행기능 등 에 민감하여 교육수준의 영향을 변별하는 데 유용하다(Lee, \& Kim, 2018).

이 밖에 본 연구에서는 정상군과 각 환자군 간의 인지-의사소통 수행력에 모두 유의미한 차이가 있었다. 특히 TBI 및 RHD 집단의 경우 표집 수가 51 명으로 적은 편이었고 경도-중등도의 환자를 대 상으로 한 점을 감안할 때, $\mathrm{BCCD}$ 를 통해 정상군과의 변별이 가능 하다는 결과는 임상적 함의가 매우 큰 것으로 간주된다. 이는 1) 두 환자군이 복합적이고 특징적인 인지-언어 문제를 갖는 점, 2) 실어 증 등의 언어장애와는 변별적인 양상을 띠는 점, 3) 두 환자군에 특 화된 국내 표준화 도구가 없는 점, 4) 진단 및 중재 시 일상적이고 기 능적인 측면을 반영할 필요성 등에 근거하여, $\mathrm{BCCD}$ 를 두 환자군 에 유용하게 적용할 수 있음을 시사한다. 예컨대, 본 연구에서 두 환 자군은 치매 및 $\mathrm{MCI}$ 집단에 비해 인지 영역의 $\mathrm{HOC}$ 나 의사소통 영역의 이해 능력이 상대적으로 낮았다. 이는 TBI와 RHD 집단이 
인지적 처리 속도, 고차원적 인지-언어 처리 등의 저하가 뚜렷해 일 상생활에서 $\mathrm{HOC}$ 나 화용언어 기능을 발휘하는 데 어려움을 겪는 다는 선행연구 결과와 일치한다(Lee, 2013). 따라서 두 환자군의 진 단 및 중재 시 이 같은 특징적 양상을 고려할 필요가 있다.

\section{신뢰도 및 타당도}

본 연구에서는 내적 일관성신뢰도, 검사자 간 및 검사자 내 신뢰 도를 통해 $\mathrm{BCCD}$ 의 신뢰도를 검증하였다. 그 결과 내적 일관성신 뢰도를 반영하는 Cronbach's $\alpha$ 계수가 .837로 높게 나타나 BCCD 의 하위 검사 및 문항에 대한 반응이 일관적임을 입증하였다. 또 검 사자 간 및 검사자 내 신뢰도는 각각 .992 와 .999 이상으로 시간의 경과에 따라서도 평가의 신뢰도가 매우 높은 것으로 분석되었다.

$\mathrm{BCCD}$ 의 내적 구성타당도를 검증하기 위해 8개 하위 검사(인지 4 , 의사소통 4)와 총점(인지/의사소통/인지-의사소통) 간의 상관관 계를 살펴보았는데, 치매군은 주의력과 화용언어를 제외한 모든 영 역 간, $\mathrm{MCI}$ 군은 화용언어와 3 개 영역 간을 제외한 모든 영역 간에 유의한 상관성이 있었다. 이는 BCCD가 ACCD의 특징적 양상을 잘 반영하는 진단도구임을 시사한다. 신경학적 변화를 예측하는 데 있어 인지와 의사소통 능력은 상호 연계적으로 작용한다. 예를 들어, 노화로 인한 인지-의사소통의 저하를 변별하는 영역으로 문 제해결력, 시지각력, 기억력, 비유언어 이해, 대면이름대기, 단어유 창성, 집행기능 등이 꼽힌다(Lee, 2017; Soares et al., 2014). 특히 집 행기능은 시각 및 구어 정보를 처리할 때 핵심적으로 관여하는데 (Ferreira et al., 2015), 이로 인해 고차원적 언어 처리를 크게 좌우한 다. 일상생활의 기능적 의사소통과도 직접적으로 연계되어 개인의 삶의 질에도 결정적인 영향을 미친다(Kumar et al., 2015). 즉 신체 적 및 기능적 과제를 수행할 때 인지적 자원의 할당을 조절함으로 써 일상생활을 영위하기 위한 여러가지 상황에 적용된다. 이로 인 해 고령화 사회의 기능적인 차원에서 더욱 강조되는 기능이다(Lee, 2017). 예컨대, 집행기능이 저하된 치매 환자는 반응 양식을 전환하 기가 어려워 이전의 기준을 고수하기 때문에 범주나 주제별 분류 등의 과제를 잘 수행하지 못한다. 즉 새로운 규칙을 채택하는 데 있 어 이전의 기준에 근거한 반응을 억제하지 못하는 양상을 보인다. 또 다른 예로 신경학적 질환군에서 두드러지는 보속증(perseveration)을 꼽을 수 있다. 본 연구의 치매군에서 집행기능이 포함된 $\mathrm{HOC}$ 가 모든 의사소통 영역과 높은 상관성을 보인 것도 이와 동일 한 맥락으로 간주된다.

단어유창성과 단어정의하기 과제로 구성된 $\mathrm{BCCD}$ 의 표현 영역 도 치매 및 $\mathrm{MCI}$ 집단의 모든 인지 영역과 상관성이 있었다. 단어유 창성은 의미기억, 작업기억, HOC 등이 연계된 복합적 신경망(neu- ral networks)을 통해 활성화되므로 신경학적 변화를 예측하는 데 매우 유용하다. 예컨대, $\mathrm{AD}$ 로 인해 의미기억 내에서 개념적 지식을 처리하는 데 어려움이 클수록 단어유창성이 저하된다(Henry, MacLeod, Phillips, \& Crawford, 2004; Reilly, Peelle, Antonucci, \& Grossman, 2011). 또 기억력과 HOC는 개념의 형성 및 추론, 의미 정보의 인출과 연계되므로 연령이 높을수록 어려움을 겪는다. 단 어정의는 문장 수준의 의미론적 표현에 그치지 않고 단어 의미의 처리, 의미 지식, $\mathrm{HOC}$ 등을 복합적으로 요하는데, 이는 $\mathrm{BCCD}$ 의 표현 영역이 인지의 모든 하위 검사와 상관성을 갖는 데 기여한 것 으로 추측된다.

$\mathrm{BCCD}$ 의 이해 및 화용언어 검사는 비유언어, 상징 및 기호, 담화, 화용 표현 등으로 구성되어 화용적 측면이 크게 반영되어 있다. 이 는 $\mathrm{ACCD}$ 의 기능적 의사소통 양상을 고려한 것으로, 본 연구결과 에서도 의사소통의 다른 하위 검사 및 인지 영역과 대체로 높은 상 관성을 보였다. 특히 치매군과 $\mathrm{MCI}$ 군의 이해 검사는 나머지 모든 인지-의사소통 영역과 상관성이 있었다. 이해 능력이 저하될수록 목표에서 벗어난 장황한 발화를 산출하고, 지나치게 많거나 모호 하며 제한적인 성격을 띤다. 이는 궁극적으로 의사소통의 효율성 과 상호작용의 질을 낮춘다(Lee \& Kim, 2019a; Pushkar Gold et al., 2000). 이 과정에서 추론력, 집행기능을 포함한 HOC, 작업기억 등 이 광범위하게 관여한다. 예컨대, $\mathrm{AD}$ 초기의 발화에는 단순하고 자동화된 문장, 목표어를 대체하는 상위 범주의 어휘, 목표어와 무 관한 발화 등이 빈번하다. 또 65 세 이상 노인의 언어 표현과 화용언 어가 HOC와 직접적인 상관성을 보인다는 보고도 있다(Lee \& Kim, 2020a). ACCD로 인해 화용적 추론에 결함을 보이면 담화의 산출 도 제한된다. 의미적 효율성, 통사적 활용, 음운 지식, 거시 구조의 정교화, 응집성과 통일성, 정보 전달의 적절성 등이 $\mathrm{HOC}$ 기제에 기 반하기 때문에 담화의 표현을 방해하는 것이다(Kemper \& Sumner, 2001; Lee \& Kim, 2020a). 본 연구의 치매군에서 화용언어 측면 이 HOC를 포함한 대부분의 인지 및 모든 의사소통 영역과 상관성 을 보인 것도 이와 동일한 맥락으로 설명된다.

반면 본 연구에서 $\mathrm{MCI}$ 집단의 화용언어는 기억력을 제외하고 주의력, 시지각력, $\mathrm{HOC}$ 와의 상관성이 유의하지 않은 것으로 나타 났다. 이는 $\mathrm{MCI}$ 의 인지-언어적 결함에 대한 논의가 연구마다 다소 논쟁적임을 반영하는 결과이다(Balthazar, Cendes, \& Damasceno, 2008). 특히 $\mathrm{BCCD}$ 의 화용언어 영역은 담화와 화용 표현으로 구성 되어, 여러 영역에 걸친 인지 처리와 언어 능력 간의 결합을 요한다. 이로 인해 $\mathrm{MCI}$ 의 변이적 양상이 화용언어와 인지 영역 간의 상관 성에 관여했을 가능성이 높다. 실제로 $\mathrm{MCI}$ 환자가 산출하는 자발 화는 경도 $\mathrm{AD}$ 와 차이가 적고 정상 노인과도 유사하다는 보고가 
있다(Folenza et al., 2009). 양자 간의 상관성에 영향을 미친 또 다 른 변인으로 $\mathrm{MCI}$ 의 하위 유형을 꼽을 수 있다. 본 연구의 $\mathrm{MCI}$ 군에 는 기억상실형, 비기억상실형, 단일영역형, 다영역형 $\mathrm{MCI}$ 가 혼재되 어 있어 유형에 따른 특징적 양상이 수행력에 작용했을 여지가 있 다. 예를 들어, 주의력, 집행기능 등 전반적 인지 능력은 $\mathrm{MCI}$ 의 하 위 유형에 따라 다르다(Folenza et al., 2009). 특히 여러 인지 영역의 손상에 기반한 다영역형 $\mathrm{MCI}$ 의 경우 단일영역형에 비해 복합적 인 지-언어 처리에 상대적으로 취약하다.

본 연구에서 $\mathrm{BCCD}$ 의 공인타당도는 K-MMSE 및 STAND를 통 해 알아보았다. 이는 1) 간편검사로서의 진단적 속성, 2) 신뢰도와 타당도가 널리 검증된 도구와의 비교(Shin, So, \& Lee, 2008), 3) 인 지 및 의사소통 관련 평가 등을 고려하였다. 특히 STAND는 본 연 구의 환자군에 포함된 실어증 집단의 의사소통 영역과 비교하는 데 활용되었다. 치매 및 $\mathrm{MCI}$, 실어증 집단의 주의력, 시지각력, 기억 력, 의사소통 총점, $\mathrm{BCCD}$ 총점은 $\mathrm{K}-\mathrm{MMSE}$ 의 각 해당 영역과 모두 유의한 상관성이 있었다. 즉 $\mathrm{BCCD}$ 의 인지 및 의사소통 영역은 $\mathrm{ACCD}$ 의 평가도구로서 충분한 적절성을 띠며 기준상관(criterionrelated) 타당도가 높은 도구임을 입증하였다.

본 연구에서 실어증 집단의 이해, 표현, 읽기/쓰기, 화용언어, 총 점은 STAND의 관련 영역인 듣고 이해하기, 이름대기, 읽기/쓰기, 그림 설명하기, 총점과 .865 이상의 높은 상관성을 보였다. 이 같은 결과는 실어증 집단에 대한 임상적 활용도를 높이는 계기가 된다 는 점에서 매우 의미가 크다. 실어증 환자는 언어 뿐 아니라 인지적 수행에도 어려움을 겪는다(Gainotti, 2014). 보편적으로 비구어적 상징이나 개념적 활동이 저해됨으로써 인지적 장애가 초래되는데, 이는 언어와 구어적 및 비구어적 인지 간의 상관성을 반영한다. 실 어증 중재의 궁극적인 목표가 예측 불가능한 요구와 상황이 존재 하는 일상생활에서 의사소통 기능을 극대화하는 데 있으므로, 목 표 중심적 행동과 유연한 문제해결, 활동 간의 전환을 위한 집행기 능 등을 필수적으로 다루어야 한다. 따라서 $\mathrm{BCCD}$ 는 실어증 환자 에 대한 언어 양식 별 접근 외에 인지-의사소통에 기반한 진단을 통 해 효과적인 중재의 기반을 마련하는 데 활용될 수 있을 것이다.

\section{변별적 기능}

CCD 관련 임상 규준 및 지침(CASLPO, 2015)에 따르면, 언어재 활사는 $\mathrm{ACCD}$ 의 유무 및 양상, 기능을 확인함으로써 평가 결과를 해석하고 중재 과정에서 적절한 인지-의사소통 평가를 지속적으로 제공해야 한다. 평가를 통해 파악한 $\mathrm{ACCD}$ 의 특성과 영향, 적용 가 능한 중재법을 공유하며, $\mathrm{ACCD}$ 를 중재하는 데 활용하거나 기여할 맥락적 요소를 고려한다. 특히 환자의 활동과 참여를 제한하는 속
성에 근거하여 중재를 계획해야 한다(WHO, 2001). 요컨대, ACCD 의 평가는 중재의 연속선상에서 시행되어야 하며, 이를 위해서는 진단적 정확도와 임상적 증상에 대한 변별이 필수적으로 전제되어 야 한다. 본 연구에서 $\mathrm{BCCD}$ 의 진단정확도는 치매 및 $\mathrm{MCI}$ 집단에 서 모두 유의하였으며, 판별기능 적중률(\%)이 각각 88.50, 88.20으 로 $\mathrm{ACCD}$ 의 평가도구로서 높은 예측력이 있음을 입증하였다.

변별력을 살펴본 선행 연구에서 Mini-Cog (Borson, Scanlan, Brush, Vitaliano, \& Dokmak, 2000) 및 ACE-R (Addenbrooke's Cognitive Examination-Revised; Mioshi, Dawson, Mitchell, Arnold, \& Hodges, 2006)은 치매를, MoCA (Montreal Cognitive Assessment; Nasreddine et al., 2005)는 MCI를 변별하는 데 유용하였 다(Tsoi, Chan, Hirai, Wong, \& Kwok, 2015). MMSE (Folstein, Folstein, \& McHugh, 1975)가 지역사회와 요양시설의 치매를 변별하는 데 유용하며 민감도와 특이도가 높다는 보고도 많다(Lin, O'Connor, Rossom, Perdue, \& Eckstrom, 2013; Mitchell \& Malladi, 2010). 예를 들어, MMSE의 진단정확도는 민감도 $81.00 \%$, 특이도 $89.00 \%$, AUC .92로 높게 제시된 바 있다(Tsoi et al., 2015). 본 연구에서 BCCD 는 치매군에서 민감도 $87.00 \%$, 특이도 $87.00 \%, \mathrm{AUC} .94, \mathrm{MCI}$ 군에 서 민감도 $89.60 \%$, 특이도 $89.10 \%, \mathrm{AUC} .95$ 로 나타났다. 이는 K$\mathrm{MMSE}$ 를 통해 검증된 공인타당도와 함께 $\mathrm{BCCD}$ 의 변별력을 배가 시키는 결과로 간주될 수 있다. 특히 BCCD가 1) ACCD에 가장 민 감한 주의력의 세부 영역인 선택 및 분리주의력, 2) 복합적 인지 체 계를 반영하는 작업기억 및 $\mathrm{HOC}, 3$ ) 화용적 및 기능적 측면에 중점 을 둔 의사소통 문항으로 다양화된 도구임을 감안할 때, K-MMSE 등 기존의 인지 선별검사에 비해 변별 기능이 큰 도구임을 알수 있다.

CLQT (Cognitive Linguistic Quick Test; Helm-Estabrooks, 2001) 가 급성기 $\mathrm{ACCD}$ 의 고차원적 인지-의사소통을 감별하는 데 유용 하다는 보고도 있다(Blyth, Scott, Bond, \& Paul, 2012). 본 연구의 치매군에는 경도-심도의 알츠하이머형 및 혈관성 치매, $\mathrm{MCI}$ 군에 는 기억상실형 및 비기억상실형, 단일영역형 및 다영역형 $\mathrm{MCI}$ 가 포 함되었다. 이와 함께 TBI 및 RHD 환자군의 변별적 기능도 검증되 었다. 따라서 $\mathrm{BCCD}$ 가 $\mathrm{ACCD}$ 의 주요 대상군을 감별하는 데 높은 변별력을 지니며, 이는 질환의 각 하위 유형에도 적용될 수 있음을 시사한다. 한편 $\mathrm{BCCD}$ 는 $\mathrm{ACCD}$ 의 주요 대상군인 치매, $\mathrm{MCI}, \mathrm{TBI} /$ $\mathrm{RHD}$ 에 대한 변별 기능에 중점을 둔 도구로서, 언어 특화적 장애인 실어증의 경우 언어 문제와 함께 동반될 수 있는 인지적 수행력을 진단하고 중재에 활용하는 데 의미를 두었다.

본 연구는 노화 및 신경학적 질환으로 인한 인지-의사소통 문제 를 진단하는 도구를 개발하고 표준화하는 데 목표를 두었다. 인지의사소통 기능에 대한 평가도구로서 $\mathrm{BCCD}$ 의 신뢰도와 타당도를 
입증했을 뿐 아니라 $\mathrm{ACCD}$ 를 감별하는 데 높은 변별력이 있음을 규명하였다. 방법론적 차원에서 간편검사 형식으로 구성되어 언어 재활 현장에서의 접근성과 활용도를 높이도록 하였다. 또 $\mathrm{ACCD}$ 의 주요 대상군인 치매, $\mathrm{MCI}, \mathrm{TBI}$ 및 $\mathrm{RHD}$ 뿐 아니라 비진행성 신경 질환에 기인한 실어증을 포괄함으로써 $\mathrm{BCCD}$ 의 적용 범주를 확대 시켰다. 즉 $\mathrm{BCCD}$ 는 1) 55세 이상의 성인, 2) 진행성 및 비진행성 신 경 질환에 기인한 $\mathrm{ACCD}, 3)$ 노화로 인한 인지-의사소통 변화 4) 주 관적 인지 호소(subjective cognitive complaints), 주관적 언어 호소 (subjective language complaints)와 같은 주관적 호소 단계 등에 광 범위하게 적용될 수 있다. $\mathrm{ACCD}$ 의 진단적 정확도를 높임으로써 궁극적으로 임상 전 및 임상 단계에서 중재를 계획하거나 중재 효 과를 제고하는 데 크게 기여할 것이다.

본 연구의 제한점은 다음과 같다. 첫째, 향후에는 환자군의 인구 통계학적 특성과 중증도, 하위 유형에 따라 세분화된 연구가 필요 할 것이다. 둘째, 본 연구에서 정상군의 선정은 K-MMSE에만 근거 하였는데, 환자군과의 변별 기능, 정상 규준의 정확도 등을 고려하 여 향후 연구에서는 이를 보다 강화할 필요가 있다. 셋째, 본 도구는 $\mathrm{ACCD}$ 의 주요 대상군인 치매, $\mathrm{MCI}, \mathrm{TBI} / \mathrm{RHD}$ 에 대한 변별 기능 에 중점을 두었다. 이로 인해 실어증의 경우 변별성보다는 언어 문 제에 동반될 수 있는 인지적 수행력을 진단하고 중재에 활용하도록 하였다. 추후에는 실어증 집단의 변별력을 제시하는 연구가 시행되 어야 할 것이다. 넷째, 내적 구성타당도 결과에서 상관성이 검증되 지 않은 영역에 대해 추가적인 보완이 필요할 것이다.

\section{REFERENCES}

American Association for the Advancement of Science (AAAS). (2009). Vision and change in undergraduate biology education: A call to action. Washington, DC: Association of American Medical Colleges.

Adamovich, B. B., \& Henderson, J. (1992). Scales of cognitive ability for traumatic brain injury. Austin, Texas: Pro-Ed.

Aguerrevere, L. (2007). Visual perception in traumatic brain injury: effects of severity and effort (Master's thesis). University of New Orleans, New Orleans, Louisiana.

Anderson, N. D., \& Craik, F. I. (2017). 50 years of cognitive aging theory. The Journals of Gerontology: Series B, Psychological Sciences and Social Sciences, 72(1), 1-6.

Anstey, K. J., \& Low, L. F. (2004). Normal cognitive changes in aging. Australian Family Physician, 33(10), 783-787.

American Speech-Language-Hearing Association (ASHA). (2005). Roles of speech-language pathologists in the identification, diagnosis, and treatment of individuals with cognitive-communication disorders: position statement. Retrived from https://www.asha.org.

Auriacombe, S., Lechevalier, N., Amieva, H., Harston, S., Raoux, N., \& Dartigues, J. F. (2006). A longitudinal study of qualitative features of category verbal fluency in incident Alzheimer's disease subjects: results from the PAQUID study. Dementia and geriatric cognitive disorders, 21(4), 260-266.

Balthazar, M. L., Cendes, F., \& Damasceno, B. P. (2008). Semantic error patterns on the Boston Naming Test in normal aging, amnestic mild cognitive impairment, and mild Alzheimer's disease: is there semantic disruption?. Neuropsychology, 22(6), 703-709.

Bayles, K. A., \& Tomoeda, C. K. (1993). The Arizona battery for communication disorders of dementia: normed edition. Phoenix, Arizona: Canyonlands Publishing, Inc.

Bayles, K. A., \& Tomoeda, C. K. (1994). Functional Linguistic Communication Inventory. Tucson, AZ: Canyonlands Publishing Co.

Bier, N., van der Linden, M., Gagnon, L., Desrosiers, J., Adam, S., Louveaux, S., \& Saint-Mleux, J. (2008). Face-name association learning in early Alzheimer's disease: a comparison of learning methods and their underlying mechanisms. Neuropsychological Rehabilitation, 18(3), 343-371.

Blyth, T., Scott, A., Bond, A., \& Paul, E. (2012). A comparison of two assessments of high-level cognitive communication disorders in mild traumatic brain injury. Brain Injury, 26(3), 234-240.

Borella, E., Carretti, B., \& De Beni, R. (2008). Working memory and inhibition across the adult life-span. Acta Psychologica, 128(1), 33-44.

Borson, S., Scanlan, J., Brush, M., Vitaliano, P., \& Dokmak, A. (2000). The Mini-Cog: a cognitive "vital signs" measure for dementia screening in multi-lingual elderly. International Journal of Geriatric Psychiatry, 15(11), 1021-1027.

Braver, T. S., Satpute, A. B., Rush, B. K., Racine, C. A., \& Barch, D. M. (2005). Context processing and context maintenance in healthy aging and early stage dementia of the Alzheimer's type. Psychology and Aging, 20(1), 3346.

Bryan, K. (1995). The Right Hemisphere Language Battery. London: Whurr.

Choi, H. J. (2012). Performances of verbal fluency task in normal elderly: effects of gender and educational level by categories. Journal of Speech-Language and Hearing Disorders, 21(2), 37-52.

Chow, T. W., Binns, M. A., Freedman, M., Stuss, D. T., Ramirez, J., Scott, C. J., \& Black, S. (2006). Overlap in frontotemporal atrophy between normal aging and patients with frontotemporal dementias. Alzheimer Disease and 
Associated Disorders, 22(4), 327-335.

Christina, P. (2018). World Alzheimer's report 2018. Alzheimer's disease international: world Alzheimer report, 1-48.

College of Audiologists and Speech Language Pathologists of Ontario (CASLPO). (2015). Practice standards and guidelines for acquired cognitive communication disorders. Toronto, Ontario: CASLPO.

Connor, L. T., Spiro, A., III, Obler, L. K., \& Albert, M. L. (2004). Change in object naming ability during adulthood. The Journal of Gerontology Series B: Psychological Sciences and Social Sciences, 59(5), 203-209.

Cornis-Pop, M., Mashima, P. A., Roth, C. R., MacLennan, D. L., Picon, L. M., Hammond, C. S., \& Frank, E. M. (2012). Guest editorial: cognitive-communication rehabilitation for combat-related mild traumatic brain injury. Journal of Rehabilitation Research and Development, 49(7), 11-32.

de Paula, J. J., \& Malloy-Diniz, L. F. (2013). Executive functions as predictors of functional performance in mild Alzheimer's dementia and mild cognitive impairment elderly. Estudos de Psicologia, 18(1), 117-124.

Edwards, J. D., Valdés, E. G., Peronto, C., Castora-Binkley, M., Alwerdt, J., Andel, R., \& Lister, J. J. (2015). The efficacy of in sight cognitive training to improve useful field of view performance: a brief report. The Journals of Gerontology: Series B, Psychological Sciences and Social Sciences, 70(3), 417422.

Ferreira, D., Correia, R., Nieto, A., Machado, A., Molina, Y., \& Barroso, J. (2015). Cognitive decline before the age of 50 can be detected with sensitive cognitive measures. Psicothema, 27(3), 216-222.

Folenza, O. V., Diniz, B. S., Nunes, P. V., Memória, C. M., Yassuda, M. S., \& Gattaz, W. F. (2009). Diagnostic transitions in mild cognitive impairment subtypes. International Psychogeriatrics, 21(6), 1088-1095.

Folstein, M. F., Folstein, S. E., \& McHugh, P. R. (1975). "Mini-mental state": a practical method for grading the cognitive state of patients for the clinician. Journal of Psychiatric Research, 12(3), 189-198.

Forbes-McKay, K. E., Shanks, M. F., \& Venneri, A. (2014). Charting the decline in spontaneous writing in Alzheimer's disease: a longitudinal study. Acta Neuropsychiatrica, 26(4), 246-252.

Frattali, C. M., Thompson, C. K., Holland, A. L., Wohl, C. B., Wenck, C. J., Slater, S. C., \& Paul, D. (2017). ASHA Functional Assessment of Communication Skills in Adults (ASHA-FACS). Maryland: ASHA.

Ganguli, M, Snitz, B. E., Lee, C. W., Vanderbilt, J., Saxton, J. A., \& Chang, C. C. (2010). Age and education effects and norms on a cognitive test battery from a population-based cohort: the Monongahela-Youghiogheny healthy aging team. Aging and Mental Health, 14(1), 100-107.
Gainotti, G. (2014). Old and recent approaches to the problem of non-verbal conceptual disorders in aphasic patients. Cortex, 53, 78-89.

Goral, M., Clark-Cotton, M., Spiro, A. III, Obler, L. K., Verkuilen, J., \& Albert, M. L. (2011). The contribution of set switching and working memory to sentence processing in older adults. Experimental Aging Research, 37(5), 516-538.

Helm-Estabrooks, N. (2001). Cognitive Linguistic Quick Test (CLQT). Examiner's manual. San Antonio, Texas: The Psychological Corporation, Harcourt Assessment Company.

Helm-Estabrooks, N. (2017). Cognitive Linguistic Quick Test-Plus (CLQT+). Bloomington, MN: Pearson Education Inc.

Helm-Estabrooks, N., \& Hotz, G. (1990). Brief Test of Head Injury. Itasca, Illinois: The Riverside Publishing Company.

Henry, J. D., MacLeod, M. S., Phillips, L. H., \& Crawford, J. R. (2004). A meta-analytic review of prospective memory and aging. Psychology and Aging, 19(1), 27-39.

Hodges, J. R., Erzinçlioglu, S., \& Patterson, K. (2006). Evolution of cognitive deficits and conversion to dementia in patients with mild cognitive impairment: a very long-term follow-up study. Dementia and Geriatric Cognitive Disorders, 21(5-6), 380-391.

Holland, A. (2010). Management of traumatic brain injury: the influence of Mark Ylvisaker. Seminars in Speech and Language, 31(3), 137-138.

Holland, A. L., Fromm, D., \& Wozniak, L. (2018). Communication Activities of Daily Living-3. Austin, Texas: Pro-Ed.

Hoogendam, Y. Y., Hofman, A., van der Geest, J. N., van der Lugt, A., \& Ikram, M. A. (2014). Patterns of cognitive function in aging: the Rotterdam study. European Journal of Epidemiology, 29(2), 133-140.

Jeong, P. Y., Sung, J. E., \& Sim, H. S. (2014). meta-analysis of cognition-focused intervention for people with mild cognitive impairment and dementia. Communication Sciences \& Disorders, 19(2), 199-212.

Kang, Y. W. (2006). A normative study of the Korean-Mini Mental State Examination (K-MMSE) in the elderly. Korean Journal of Psychology: General, 25(2), 1-12.

Kemper, S., \& McDowd, J. (2006). Eye movements of young and older adults while reading with distraction. Psychology and Aging, 21(1), 32-39.

Kemper, S., Schmalzried, R., Hoffman, L., \& Herman, R. (2010). Aging and the vulnerability of speech to dual task demands. Psychology and Aging, 25(4), 949-963.

Kemper, S., \& Sumner, A. (2001). The structure of verbal abilities in young and older adults. Psychology and Aging, 16(2), 312-322. 
Kim, B. S., \& Lee, M. S. (2019a). Comparison of coherence and efficiency in discourse production of middle-old and old-old elderly. Audiology and Speech Research, 15(1), 63-70.

Kim, B. S., \& Lee, M. S. (2019b). Effects of reading and writing intervention on word retrieval of people with dementia. Journal of Special Education and Rehabilitation Science, 58(2), 217-236.

Kim, H., Heo, J. H., Kim, D. Y., \& Kim, J. W. (2008). Screening test for aphasia and neurologic-communication disorders. Seoul: Hakjisa.

Kim, H., \& Na, D. L. (2001). Paradise Korean version-Western aphasia battery. Seoul: Paradise Welfare Foundation.

Kim, H., \& Na, D. L. (2012). Paradise Korea-Western Aphasia Battery (Revised). Seoul: Paradise Welfare Foundation.

Kim, S. R., \& Kim, H. (2017). Age-related changes in word defining abilities in concrete and abstract nouns with normal elderly. Journal of Rehabilitation Research, 21(3), 187-207.

Kim, Y. S., \& Yoon, J. H. (2016). Characteristics of the defining ability of the elderly in nouns, verbs, and adjectives. Communication Sciences \& Disorders, 21(2), 271-283.

Kumar, R., Koirala, P., \& Tiwari, S. C. (2015). Higher mental functioning in dementia: a status assessment. Journal of Geriatric Mental Health, 2(1), 4245.

Labouvie-Vief, G., \& Diehl, M. (1999). Self and personality development. In J. C. Cavanaugh \& S. K. Whitbourne (Eds.), Gerontology: an interdisciplinary perspective (pp. 238-268). New York: Oxford University Press.

Lee, M. S. (2013). Development and application of cognitive-pragmatic language ability assessment protocol for traumatic brain injury (CAPTBI) (Doctoral dissertation). University of Yonsei, Seoul.

Lee, M. S. (2015). Meta-analysis of correlation between cognitive-linguistic ability and cognitive reserve in normal aging. Journal of Korean Contents Society, 15(11), 359-373.

Lee, M. S. (2017). Linguistic predictors of cognition in aging. Journal of Special Education and Rehabilitation Science, 56(2), 237-262.

Lee, M. S., \& Baik, Y. J. (2020). Glossary of neurogenic language-speech disorders. Seoul: Hakjisa.

Lee, M. S., \& Kim, B. S. (2018). Correlation between figurative language and cognitive-linguistic ability in older adults by age. Journal of Special Education and Rehabilitation Science, 57(4), 115-137.

Lee, M. S., \& Kim, B. S. (2019a). A preliminary study for the development of brief test of cognitive-communication disorders (BCCD). Journal of Special Education and Rehabilitation Science, 58(4), 321-344.
Lee, M. S., \& Kim, B. S. (2019b). Characteristics of word fluency in healthy aging and Alzheimer's disease. Audiology and Speech Research, 15(2), 135143.

Lee, M. S., \& Kim, B. S. (2020a). Higher order cognition and communication: a preliminary study for the development of brief test of cognitivecommunication disorders. Audiology and Speech Research, 16(3), 236-244.

Lee, M. S., \& Kim, B. S. (2020b). Effects of working memory intervention on language production by individuals with dementia. Neuropsychological Rehabilitation, [Epub]. https://doi.org/10.1080/09602011.2020.1789479.

Lee, M. S., \& Kim, B. S. (2020c) A preliminary study for the development of informant-report scale on cognitive-linguistic abilities of the elderly: focused on mild cognitive impairment and Alzheimer's disease. Audiology and Speech Research, 16(2):167-174.

Lee, S., Kawachi, I., Berkman, L. F., \& Grodstein, F. (2003). Education, other socio-economic indicators, and cognitive function. American Journal of Epidemiology, 157(8), 712-720.

Lezak, M. D., Howieson, D. B, \& Loring, D. W. (2004). Neuropsychological Assessment (4th ed.). NY: Oxford University Press.

Lin, J. S., O'Connor, E., Rossom, R. C., Perdue, L. A., \& Eckstrom, E. (2013). Screening for cognitive impairment in older adults: a systematic review for the US preventive services task force. Annals of Internal Medicine, 159(9), 601-612.

MacDonald, S., \& Wiseman-Hakes, C. (2010). Knowledge translation in ABI rehabilitation: a model for consolidating and applying the evidence for cognitive-communication interventions. Brain Injury, 24(3), 486-508.

MacPherson, S. E., Phillips, L. H., \& Della Sala, S. (2002). Age, executive function, and social decision making: a dorsolateral prefrontal theory of cognitive aging. Psychology and Aging, 17(4), 598-609.

Martin, N., Minkina, I., Kohen, F. P., \& Kalinyak-Fliszar, M. (2018). Assessment of linguistic and verbal short-term memory components of language abilities in aphasia. Journal of Neurolinguistics, 48, 199-225.

Mioshi, E., Dawson, K., Mitchell, J., Arnold, R., \& Hodges, J. R. (2006). The Addenbrooke's cognitive examination-revised (ACE-R): a brief cognitive test battery for dementia screening. International Journal of Geriatric Psychiatry, 21(11), 1078-1085.

Mitchell, A. J., \& Malladi, S. (2010). Screening and case finding tools for the detection of dementia, part I: evidence-based meta-analysis of multidomain tests. The American Journal of Geriatric Psychiatry, 18(9), 759-782.

Mortimer, J. A., Snowdon, D. A., \& Markesbery, W. R. (2003). Head circumference, education and risk of dementia: findings from the nun study. Jour- 
nal of Clinical and Experimental Neuropsychology, 25(5), 671-679.

Nasreddine, Z. S., Phillips, N. A., Bédirian, V., Charbonneau, S., Whitehead, V., Collin, I., ..., \& Chertkow, H. (2005). The Montreal Cognitive Assessment, MoCA: a brief screening tool formild cognitive impairment. Journal of the American Geriatrics Society, 53(4), 695-699.

Peach, R. K., \& Shapiro, L. P. (2020). Cognition and acquired language disorders: an information processing approach. (1st ed., M. S. Lee \& S. R. Kim, Trans.). Elsevier-Health Sciences Division.

Pushkar Gold, D., Basevitz, P., Arbuckle, T., Nohara-LeClair, M., Lapidus, S., \& Peled, M. (2000). Social behavior and off-target verbosity in elderly people. Psychology and Aging, 15(2), 361-374.

Reilly, J., Peelle, J. E., Antonucci, S. M., \& Grossman, M. (2011). Anomia as a marker of distinct semantic memory impairments in Alzheimer's disease and semantic dementia. Neuropsychology, 25(4), 413-426.

Ruffman, T., Murray, J., Halberstadt, J., \& Taumoepeau, M. (2010). Verbosity and emotion recognition in older adults. Psychology and Aging, 25(2), 492497.

Shin, H. H., So, H. Y., \& Lee, A. Y. (2008). Comparing clinical usefulness of cognitive function tests. The Korean Journal of Rehabilitation Nursing, 11(2), 90-98.

Shin, J. (2008). Phoneme and syllable frequencies of Korean based on the analysis of spontaneous speech data. Communication Sciences \& Disorders, 13(2), 193-215.

Singh-Manoux, A., Kivimaki, M., Glymour, M. M., Elbaz, A., Berr, C., Ebmeier, K. P., .., \& Dugravot, A. (2012). Timing of onset of cognitive decline: results from Whitehall II prospective cohort study. British Medical Journal, 344, d7622.

Soares, F. C., de Oliveira, T. C., de Macedo, L. D., Tomás, A. M., Picanço-Diniz, D. L., Bento-Torres, J., ..., \& Picanço-Diniz, C. W. (2014). CANTAB object recognition and language tests to detect aging cognitive decline: an exploratory comparative study. Clinical Interventions in Aging, 10, 37-48.

Stern, Y. (2009). Cognitive reserve. Neuropsychologia, 47(10), 2015-2028.

Thompson-Schill, S. L. (2002). Effects of frontal lobe damage on interference effects in working memory. Cognitive, Affective, and Behavioural Neuroscience, 2(2), 109-120.

Treitz, F. H., Heyder, K., \& Daum, I. (2007). Differential course of executive control changes during normal aging. Neuropsychology, Development and Cognition. Section B: Aging Neuropsychology and Cognition, 14(4), 370-393.

Trunk, D. L., \& Abrams, L. (2009). Do younger and older adults' communicative goals influence off-topic speech in autobiographical narratives?. Psychology and Aging, 24(2), 324-337.

Tsoi, K. K. F., Chan, J. Y. C., Hirai, H. W., Wong, S. Y. S., \& Kwok, T. C. Y. (2015). Cognitive tests to detect dementia: a systematic review and meta-analysis. JAMA Internal Medicine, 175(9), 1450-1458.

Uekermann, J., Thoma, P., \& Daum, I. (2008). Proverb interpretation changes in aging. Brain and Cognition, 67(1), 51-57.

Unsworth, N., Spillers, G. J., \& Brewer, G. A. (2012). The role of working memory capacity in autobiographical retrieval: individual differences in strategic search. Memory, 20(2), 167-176.

Vohn, R. (2008). Functional networks of within-and cross-modal divided attention (Doctoral dissertation). University of Aachen, Germany.

Wang, J., Wang, L., Zhou, X., Wen, X., \& Zhen, X. (2019). Risk factors for predicting progression from normal cognition to mild cognitive impairment: protocol for a systematic review and meta-analysis of cohort studies. BMJ Open, 9(6), e027313.

World Health Organization (WHO). (2001). The international classification of functioning disability and health. ICD, Geneva. 
Appendix 1. Assessment protocols for ACCD

\begin{tabular}{|c|c|c|}
\hline Main area & Protocol & Subdomain \\
\hline \multirow[t]{6}{*}{ Cognitive-communication of ACCD } & $A B C D$ & $\begin{array}{l}\text { Verbal episodic memory, visuospatial construction } \\
\text { Linguistic expression, linguistic comprehension }\end{array}$ \\
\hline & SCATBI & Orientation, memory, organization, reasoning \\
\hline & BTH & $\begin{array}{l}\text { Attention, orientation, memory, organization } \\
\text { Communication (naming, reading, etc.) }\end{array}$ \\
\hline & RHLB & $\begin{array}{l}\text { Reasoning } \\
\text { Communication (figurative language, humor, etc.) }\end{array}$ \\
\hline & CLQT & $\begin{array}{l}\text { Attention, executive functions, visuospatial skills, etc. } \\
\text { Confrontation/Generative naming, spontaneous speech, etc. }\end{array}$ \\
\hline & Burns Inventory & $\begin{array}{l}\text { Numerical reasoning, factual memory, visual perception, etc. } \\
\text { Auditory comprehension, prosody, abstract language, etc. }\end{array}$ \\
\hline \multirow[t]{2}{*}{ Cognitive-communication of aphasia } & CLOT+ & $\begin{array}{l}\text { Attention, executive functions, visuospatial skills, etc. } \\
\text { Personal Facts, repetition, semantic comprehension, etc. }\end{array}$ \\
\hline & TALSA & $\begin{array}{l}\text { Repetition span, short-term memory } \\
\text { Semantic/Phonological word processing }\end{array}$ \\
\hline \multirow[t]{3}{*}{ Functional cognitive-communication } & ASHA-FACS & $\begin{array}{l}\text { Executive function (daily planning) } \\
\text { Social communication, number concepts, etc. }\end{array}$ \\
\hline & CADL-3 & Communication (figurative language, humor, writing, etc.) \\
\hline & $\mathrm{FLCl}$ & $\begin{array}{l}\text { Pantomime, gesture } \\
\text { Naming, writing, sign comprehension, etc. }\end{array}$ \\
\hline
\end{tabular}

ACCD = acquired cognitive-communication disorders; $A B C D=$ Arizona Battery for Communication Disorders of Dementia (Bayles \& Tomoeda, 1993); SCATBI= Scales of Cognitive Ability of TBI (Adamovich \& Henderson, 1992); BTHI= Brief Test of Head Injury (Helm-Estabrooks \& Hotz, 1990); RHLB=Right Hemisphere Language Battery (Bryan, 1995); CLOT=Cognitive Linguistic Quick Test (Helm-Estabrooks, 2001); CLQT+=Cognitive Linguistic Quick Test-Plus (Helm-Estabrooks, 2017), TALSA= Temple Assessment of Language and Short-term Memory in Aphasia (Martin et al., 2018); ASHA-FACS=ASHA Functional Assessment of Communication Skills in Adults (Frattali et al., 2017); CADL3 =Communication Activities of Daily Living-3 (Holland et al., 2018); FLCl= Functional Linguistic Communication Inventory (Bayles \& Tomoeda, 1994) 
Appendix 2. Internal construct validity of BCCD

(1) Dementia group

\begin{tabular}{|c|c|c|c|c|c|c|c|c|c|c|}
\hline Domain & Attention & $\begin{array}{l}\text { Visuopercep- } \\
\text { tion }\end{array}$ & Memory & $\mathrm{HOC}$ & $\begin{array}{l}\text { Comprehen- } \\
\text { sion }\end{array}$ & Expression & $\begin{array}{c}\text { Reading/ } \\
\text { Writing }\end{array}$ & $\begin{array}{l}\text { Pragmatic } \\
\text { language }\end{array}$ & $\begin{array}{c}\text { Cognitive } \\
\text { total }\end{array}$ & $\begin{array}{c}\text { Communica- } \\
\text { tion total }\end{array}$ \\
\hline Visuoperception & $.207^{*}$ & & & & & & & & & \\
\hline Memory & $.409 * *$ & $.257^{* *}$ & & & & & & & & \\
\hline $\mathrm{HOC}$ & $.578^{* *}$ & $.191^{*}$ & $.485^{* *}$ & & & & & & & \\
\hline Comprehension & $.586^{* *}$ & $.337^{* *}$ & $.449^{* *}$ & $.634^{* *}$ & & & & & & \\
\hline Expression & $.382^{* *}$ & $.249^{* *}$ & $.690^{* *}$ & $.562^{* *}$ & $.547^{* *}$ & & & & & \\
\hline Reading/Writing & $.313^{* *}$ & $.467^{* *}$ & $.294^{* *}$ & $.367^{* *}$ & $.515^{* *}$ & $.422^{* *}$ & & & & \\
\hline Pragmatic language & .171 & $.442^{* *}$ & $.321^{* *}$ & $.302^{* *}$ & $.210^{*}$ & $.361^{* *}$ & $.377^{* *}$ & & & \\
\hline Cognitive total & $.733^{* *}$ & $.358^{* *}$ & $.730^{* *}$ & $.908^{* *}$ & $.715^{* *}$ & $.668^{* *}$ & $.439^{* *}$ & $.355^{* *}$ & & \\
\hline Communication total & $.531^{* *}$ & $.464^{* *}$ & $.603^{* *}$ & $.661^{* *}$ & $.848^{* *}$ & $.799 * *$ & $.714^{* *}$ & $.568^{* *}$ & $.769 * *$ & \\
\hline BCCD total & $.669^{* *}$ & $.417^{* *}$ & $.718^{* *}$ & $.837^{* *}$ & $.809^{* *}$ & $.775^{* *}$ & $.601^{* *}$ & $.496^{* *}$ & $.943^{* *}$ & $.927^{* *}$ \\
\hline
\end{tabular}

$\mathrm{BCCD}=$ Brief test of Cognitive-Communication Disorders; $\mathrm{HOC}=$ Higher order cognition. ${ }^{*} p<.05,{ }^{* *} p<.01$.

(2) MCl group

\begin{tabular}{|c|c|c|c|c|c|c|c|c|c|c|}
\hline Domain & Attention & $\begin{array}{l}\text { Visuopercep- } \\
\text { tion }\end{array}$ & Memory & $\mathrm{HOC}$ & $\begin{array}{l}\text { Comprehen- } \\
\text { sion }\end{array}$ & Expression & $\begin{array}{l}\text { Reading/ } \\
\text { Writing }\end{array}$ & $\begin{array}{l}\text { Pragmatic } \\
\text { language }\end{array}$ & $\begin{array}{c}\text { Cognitive } \\
\text { total }\end{array}$ & $\begin{array}{c}\text { Communica- } \\
\text { tion total }\end{array}$ \\
\hline Visuoperception & $.523^{* *}$ & & & & & & & & & \\
\hline Memory & $.666^{* *}$ & $.572^{* *}$ & & & & & & & & \\
\hline $\mathrm{HOC}$ & $.872^{* *}$ & $.536^{* *}$ & $.650^{* *}$ & & & & & & & \\
\hline Comprehension & $.855^{* *}$ & $.577^{* *}$ & $.694^{* *}$ & $.878^{* *}$ & & & & & & \\
\hline Expression & $.576^{* *}$ & $.301^{* *}$ & $.661^{* *}$ & $.542^{* *}$ & $.571^{* *}$ & & & & & \\
\hline Reading/Writing & $.579^{* *}$ & $.453^{* *}$ & $.635^{* *}$ & $.566^{* *}$ & $.669^{* *}$ & $.730^{* *}$ & & & & \\
\hline Pragmatic language & .194 & .187 & $.315^{* *}$ & .129 & $.229^{*}$ & $.398^{* *}$ & $.507^{* *}$ & & & \\
\hline Cognitive total & $.919^{* *}$ & $.646^{* *}$ & $.778^{* *}$ & $.965^{* *}$ & $.916^{* *}$ & $.601^{* *}$ & $.645^{* *}$ & .201 & & \\
\hline Communication total & $.767^{* *}$ & $.511^{* *}$ & $.766^{* *}$ & $.749^{* *}$ & $.848^{* *}$ & $.849^{* *}$ & $.866^{* *}$ & $.550^{* *}$ & $.826^{* *}$ & \\
\hline BCCD total & $.891^{* *}$ & $.613^{* *}$ & $.808^{* *}$ & $.910^{* *}$ & $.926^{* *}$ & $.743^{* *}$ & $.777^{* *}$ & $.372^{* *}$ & $.965^{* *}$ & $.944^{* *}$ \\
\hline
\end{tabular}

$\mathrm{MCl}=$ Mild cognitive impairment; $\mathrm{BCCD}=$ Brief test of Cognitive-Communication Disorders; $\mathrm{HOC}=$ Higher order cognition. ${ }^{*} p<.05,{ }^{* *} p<.01$. 


\section{국문초록}

\section{인지-의사소통장애 간편검사(BCCD)의 신뢰도 및 타당도 연구}

이미숙 $\cdot$ 김보선 ${ }^{2}$ 임재성 3

'한림국제대학원대학교 청각언어치료학과· 한림청각언어연구소, ${ }^{2}$ 연세언어청각연구원, ${ }^{3}$ 한림대학교 성심병원

배경 및 목적: 고령화에 따라 후천적 인지-의사소통장애가 급증할 것으로 보인다. 이로 인해 언어재활 현장에서 활용할 수 있는 국내 표준화 도구가 필요하다. 이에 본 연구는 인지-의사소통장애 간편검사(Brief test of Cognitive-Communication Disorders, BCCD)를 개 발하고 신뢰도 및 타당도를 검증하고자 하였다. 방법: 본 연구에 참여한 정상군 $(\mathrm{n}=609)$ 은 55 세 이상 성인으로 연령 및 교육연수에 따 라 세분화되었다. 환자군은 치매 116 명, MCI 92명, TBI 및 RHD 51명, 실어증 87명으로 구성되었다. 예비 문항 개발, 전문가 검토, 안면타 당도 구축을 거쳐 27 개 인지-의사소통 문항으로 구성된 $\mathrm{BCCD}$ 를 개발한 후 각 대상군에 적용하였다. 결과: 본 연구의 주요 결과는 다 음과 같다. 첫째, $\mathrm{BCCD}$ 의 내적 일관성신뢰도, 검사자 간 및 검사자내 신뢰도가 높게 나타났다. 둘째, $\mathrm{BCCD}$ 의 내적 구성타당도를 분석 한 결과 대다수 하위 검사와 총점 간의 상관관계가 유의하였고, 인지 및 의사소통 영역에 관한 공인타당도가 검증되었다. 셋째, $\mathrm{BCCD}$ 의 진단정확도, 민감도 및 특이도가 비교적 높은 것으로 분석되었다. 논의 및 결론: 본 연구를 통해 $\mathrm{BCCD}$ 가 인지-의사소통장애 평가 도구로서 높은 신뢰도와 타당도를 지니며 ACCD를 감별할 수 있는 변별력이 있음을 입증하였다. 이에 근거하여 노화, $\mathrm{ACCD}$, 실어증으 로 인한 인지-의사소통 양상을 파악하는 데 활용할 수 있으며, 궁극적으로 인지-의사소통 중재를 계획하거나중재 효과를 제고하는 데 기여할 것이다.

핵심어: 후천적 인지-의사소통장애, 신뢰도, 타당도, 인지-의사소통장애 평가도구

\section{참고문헌}

강연욱 (2006). K-MMSE의 노인 규준 연구. 한국심리학회지: 일반, 25(2), 1-12.

김보선, 이미숙 (2019a). 중고령층과 초고령층 담화 산출의 통일성과 효율성 비교. Audiology and Speech Research, 15(1), 63-70.

김보선, 이미숙 (2019b). 읽기 및 쓰기 중재가 치매환자의 어휘산출 능력에 미치는 영향. 특수교육재활과학연구, 58(2), 217-236.

김수련, 김향희 (2017). 노화에 따른 구체명사와 추상명사의 단어정의하기 능력 변화. 재활복지, 21(3), 187-207.

김예슬, 윤지혜 (2016). 노화에 따른 명사, 동사, 형용사 정의하기 특성. Communication Sciences \& Disorders, 21(2), 271-283.

김향희, 나덕렬 (2001). 파라다이스. 한국판-웨스턴 실어증 검사. 서울: 파라다이스 복지재단.

김향희, 나덕렬 (2012). 파라다이스 한국판 웨스턴 실어증 검사 개정판. 서울: 파라다이스 복지재단.

김향희, 허지회, 김덕용, 김정완 (2008). 실어증-신경언어장애 선별검사. 서울: 학지사 심리검사연구소.

신지영 (2008). 성인 자유 발화 자료 분석을 바탕으로 한 한국어의 음소 및 음절 관련 빈도. Communication Sciences \& Disorders, 13(2), 193-215.

신홍현, 소희영, 이애영 (2008). 치매 환자 인지기능 검사(CDT, K-MMSE, K-3MS, CDR)의 임상적 유용성 비교. 재활간호학회지, 11(2), 90-98.

이미숙 (2013). 외상성 뇌손상 환자의 인지-화용언어 능력에 대한 평가도구 개발 및 적용. 연세대학교 대학원 박사학위논문.

이미숙 (2015). 정상 노년층의 인지-언어 능력과 인지 보존능력 간 상관성에 관한 메타분석. 한국콘텐츠학회논문지, 15(11), 359-373.

이미숙 (2017). 노인의 인지능력에 대한 언어적 예측변인. 특수교육재활과학연구, 56(2), 237-262.

이미숙, 김보선 (2018). 연령층에 따른 노인의 비유언어 이해와 인지-언어 능력 간 상관성. 특수교육재활과학연구, 57(4), 115-137.

이미숙, 김보선 (2019a). 인지-의사소통장애 간편검사(BCCD) 개발을 위한 예비연구. 특수교육재활과학연구, 58(4), 321-344.

이미숙, 김보선 (2019b). 정상 노인과 치매 환자의 단어유창성 특성. Audiology and Speech Research, 15(2), 135-143.

이미숙, 김보선 (2020a). Higher order cognition and communication: A preliminary study for the development of brief test of cognitive-communication disorders. Audiology and Speech Research, 16(3), 236-244. 
이미숙, 김보선 (2020c). A Preliminary Study for the Development of Informant-Report Scale on Cognitive-Linguistic Abilities of the Elderly: Focused on Mild Cognitive Impairment and Alzheimer's Disease. Audiology and Speech Research, 16(2), 167-174. 이미숙, 백려정 (2020). 신경언어장애 용어집. 서울: 학지사.

정필연, 성지은, 심현섭 (2014). MCI와 치매환자를 위한 인지기반 중재의 효과에 대한 메타분석. Communication Sciences \& Disorders, 19(2), 199212 .

최현주 (2012). 고령자의 구어유창성 과제 수행력: 범주별 성별 및 교육정도에 따른 차이. 언어치료연구, 21(2), 37-52.

Richard K. Peach \& Lewis P. Shapiro (2020). 인지-의사소통장애: 정보 처리 접근(제1판, 이미숙, 김수련 역). 서울: 학지사.

\section{ORCID}

이미숙(제1저자, 교수 https://orcid.org/0000-0001-9255-565X); 김보선(교신저자, 언어재활사 https://orcid.org/0000-0002-8351-1417);

임재성(공동저자, 교수 https://orcid.org/0000-0001-6157-2908) 